\title{
Structural diversity and biological activities of caged Garcinia xanthones: recent updates
}

\author{
Yee Lin Phang ${ }^{a, b}$, Changwu Zheng ${ }^{a, b, *}$ and Hongxi $X^{a, b, *}$ \\ aschool of Pharmacy, Shanghai University of Traditional Chinese Medicine, Shanghai 201203, China \\ bEngineering Research Center of Shanghai Colleges for TCM New Drug Discovery, Shanghai 201203, China
}

*Correspondence: xuhongxi88@gmail.com (H.X.); zhengcw@shutcm.edu.cn (C.Z.)

Received: 06 January 2022; Revised: 06 February 2022; Accepted: 07 February 2022

Published online: February 172022

DOI 10.15212/AMM-2022-0001

\begin{abstract}
Caged xanthones are a class of natural compounds with approximately 200 members that are commonly isolated from the Garcinia genus in the Clusiaceae (formerly Guttiferae) family. They are often characterized by a notable 4-oxatricyclo[4.3.1.0 $0^{3,7}$ ]dec-2-one (caged) architecture with a common xanthone backbone. Because most caged xanthones have potent anticancer properties, they have become a target of interest in natural product chemistry. The unique chemical architectures and increasingly identified biological importance of these compounds have stimulated many studies and intense interest in their isolation, biological evaluation and mechanistic studies. This review summarizes recent progress and development in the chemistry and biological activity of caged Garcinia xanthones and of several compounds of non-Garcinia origin, from the years 2008 to 2021, providing an in-depth discussion of their structural diversity and medicinal potential. A preliminary discussion on structure-activity relationships is also provided.
\end{abstract}

Keywords: caged xanthone, gambogenic acid, isomorellin, neobractatin, anticancer, structure-activity relationship

\section{INTRODUCTION}

Garcinia is a pantropical genus of plants consisting of more than 400 species native to South America, Africa, India and East Asia [1, 2]. For their long history, the fruits, pericarp, epicarp and seeds of Garcinia species have been used in traditional medicine for treating ulcers, wounds, suppuration, dysentery and diarrhea [3,4]. The chemical constituents in the extract of this genus are rich in polyphenols, flavonoids, polyprenylated acylphloroglucinols and xanthones [5]. Among them, the xanthones, particularly caged xanthones, have become a subject of intense interest among the scientific community because of their medicinal potential, particularly in cancer treatment. For instance, the most representative caged xanthone, gambogic acid, has been approved by the China Food and Drug Administration for phase II clinical trials involving intravenous treatment of lung cancer [6, 7].

Until 2008, approximately 100 natural caged Garcinia xanthones with diverse molecular connectivity had been discovered and isolated, mainly from Garcinia hanburyi [8], G. morella [9], G. gaudichaudii [10], G. scortechinii [11], and G. bracteata [12], according to our previous review [13]. Considerable progress on the phytochemistry of caged xanthones has since been made, and 96 new compounds have been isolated in the past decade
(Table 1). Most of the caged xanthones feature an unusual 4-oxa-tricyclo[4.3.1.0 3,7]dec-2-one (caged) scaffold [40] with a polyprenylated xanthone backbone, and show versatile pharmacological properties including anticancer [41, 42], antiviral [43], antibacterial [8], antiatherosclerosis [44] and neurotrophic activities [45].

Three key reviews exploiting the chemistry and biology of caged Garcinia xanthones have described [13, 46, 47], the most recent of which was published by the Reutrakul group in 2012 [47]. Numerous reviews by several research teams have focused on xanthone compounds, a small subset of which are caged xanthones [48-56]. In addition, the therapeutic potential of gambogic acid has recently been highlighted in several elegant reviews [5760] and a book section [61]. Herein, this review does not attempt to overlap with those excellent published works but instead focuses on the structural diversity and biological investigation of newly isolated caged xanthone compounds from the years 2008 to 2021. Reports with keywords "caged xanthone," "caged polyprenylated xanthonoid," "caged Garcinia xanthone" and the names of several bioactive caged xanthones, such as "gambogic acid," "gambogenic acid," "isomorellin" and "neobractatin" found in major scientific databases such as Google Scholar, Web of Science, PubMed and ScienceDirect were compiled and analyzed. 
Acta

Materia

Medica

Table 1 | Isolated caged xanthones reported from 2008 to 2021 and associated cytotoxicity*

\begin{tabular}{|c|c|c|c|c|c|}
\hline & Compound & Source & Cell lines & $\mathrm{IC}_{50}(\mu \mathrm{M})$ & Ref. \\
\hline 1 & Gambogic aldehyde & G. hanburyi & P388 & 0.24 & [14] \\
\hline 2 & 7-Methoxyisomorellinol & G. hanburyi & HeLa & 1.2 & [15] \\
\hline 3 & 7-Methoxygambogic acid & G. hanburyi & HeLa & 0.93 & [15] \\
\hline 4 & 7-Methoxyepigambogic acid & G. hanburyi & HeLa & 0.85 & [15] \\
\hline 5 & Oxygambogic acid & G. hanburyi & HeLa & 1.9 & [15] \\
\hline 6 & 11,12-Dihydro-12-hydroxymorellic acid & G. lateriflora & HT-29 & $2.9^{a}$ & [16] \\
\hline 7 & Isogaudichaudiic acid E & G. lateriflora & HT-29 & $2.6^{\mathrm{a}}$ & [16] \\
\hline 8 & Wightiic acid & G. wightii & A-375 & 4.7 & [17] \\
\hline 9 & 16-O-methyl wightiic acid & G. wightii & - & - & [17] \\
\hline 10 & Garcioligantone G & G. oligantha & $\begin{array}{l}\text { A549 } \\
\text { HeLa } \\
\text { PC-3 }\end{array}$ & $\begin{array}{l}3.7 \\
3.6 \\
4.3\end{array}$ & [18] \\
\hline 11 & Garcioligantone H & G. oligantha & - & - & [18] \\
\hline 12 & Oliganthone B & G. oligantha & $\begin{array}{l}\text { A549 } \\
\text { HepG2 } \\
\text { HT-29 } \\
\text { PC-3 }\end{array}$ & $\begin{array}{l}3.9 \\
4.5 \\
4.8 \\
4.6\end{array}$ & [19] \\
\hline 13 & Epiisobractatin & G. bracteata & $\begin{array}{l}\text { A549 } \\
\text { HL-60 } \\
\text { HT-29 } \\
\text { K562 } \\
\text { WPMY-1 }\end{array}$ & $\begin{array}{l}4.7 \\
1.2^{b} \\
3.9 \\
2.1^{b} \\
2.7\end{array}$ & {$[20,21]$} \\
\hline 14 & 13-Hydroxyepiisobractatin & G. bracteata & $\begin{array}{l}\mathrm{HL}-60 \\
\mathrm{~K} 562\end{array}$ & $\begin{array}{l}1.1^{b} \\
2.1^{b}\end{array}$ & {$[20]$} \\
\hline 15 & 13-Hydroxyisobractatin & G. bracteata & $\begin{array}{l}\mathrm{HL}-60 \\
\mathrm{~K} 562\end{array}$ & $\begin{array}{l}1.1^{b} \\
2.1^{b}\end{array}$ & {$[20]$} \\
\hline 16 & Epicantleyanone B & G. oligantha & $\begin{array}{l}\text { A549 } \\
\text { HeLa } \\
\text { PC-3 }\end{array}$ & $\begin{array}{l}2.6 \\
1.9 \\
2.1\end{array}$ & [18] \\
\hline 17 & 11-Methoxyepicantleyanone B & G. oligantha & - & - & [18] \\
\hline 18 & Garcioligantone C & G. oligantha & HeLa & 3.6 & [18] \\
\hline 19 & Garcioligantone D & G. oligantha & $\begin{array}{l}\text { A549 } \\
\text { HeLa } \\
\text { K562 } \\
\text { PC-3 }\end{array}$ & $\begin{array}{l}4.4 \\
2.6 \\
4.6 \\
2.7\end{array}$ & [18] \\
\hline 20 & Garcioligantone E & G. oligantha & - & - & [18] \\
\hline 21 & $\begin{array}{l}\text { Garcioligantone F or } \\
\text { oliganthone } E\end{array}$ & G. oligantha & PC-3 & 4.6 & {$[18,22]$} \\
\hline 22 & Gambogenific acid & G. hanburyi & $\begin{array}{l}\text { HCT-116 } \\
\text { HeLa } \\
\text { HUVEC }\end{array}$ & $\begin{array}{l}4.5 \\
1.8 \\
2.5\end{array}$ & {$[15,23]$} \\
\hline 23 & Gambogefic acid A & G. hanburyi & HeLa & 2.1 & {$[24]$} \\
\hline 24 & 12-Hydroxygambogefic acid A & G. hanburyi & $\begin{array}{l}\text { HCT-116 } \\
\text { MDA-MB-231 }\end{array}$ & $\begin{array}{l}2.1 \\
2.2\end{array}$ & {$[25]$} \\
\hline 25 & Gambogefic acid & G. hanburyi & HeLa & 0.5 & [15] \\
\hline
\end{tabular}

Acta Materia Medica 2022, Volume 1, Issue 1, p. 72-95 73 
Table 1 | Continued

\begin{tabular}{|c|c|c|c|c|c|}
\hline & Compound & Source & Cell lines & $\mathrm{IC}_{50}(\mu \mathrm{M})$ & Ref. \\
\hline 26 & 7-Methoxygambogellic acid & G. hanburyi & HeLa & 0.9 & [15] \\
\hline 27 & Gambogellic acid A & G. hanburyi & HeLa & 1.7 & {$[24]$} \\
\hline 28 & Gambogollic acid & G. hanburyi & $\begin{array}{l}\text { A549 } \\
\text { SMMC-7721 }\end{array}$ & $\begin{array}{l}1.1 \\
1.5\end{array}$ & {$[26]$} \\
\hline 29 & Epigambogollic acid & G. hanburyi & $\begin{array}{l}\text { A549 } \\
\text { SMMC-7721 }\end{array}$ & $\begin{array}{l}1.6 \\
1.8\end{array}$ & [26] \\
\hline 30 & Doitunggarcinone $\mathrm{K}$ & $\begin{array}{l}\text { G. propinqua, } \\
\text { G. bracteata }\end{array}$ & T98 & 3.5 & {$[27,28]$} \\
\hline 31 & 3-O-Geranylforbesione & G. hanburyi & HeLa & 4.1 & [15] \\
\hline 32 & 3-O-Methylbractatin & $\begin{array}{l}\text { G. propinqua, } \\
\text { G. bracteata }\end{array}$ & $\begin{array}{l}\text { A549 } \\
\text { HCT-116 } \\
\text { HL-60 } \\
\text { MCF-7 } \\
\text { SMMC-7721 } \\
\text { SW480 }\end{array}$ & $\begin{array}{l}0.7 \\
\text { (-)-isomer: } 1.5 \\
\text { (+)-isomer: } 3.4 \\
0.2 \\
0.3 \\
0.2 \\
0.5\end{array}$ & [29-31] \\
\hline 33 & Isogaudichaudiic acid B & G. lateriflora & - & - & [16] \\
\hline 34 & Isogaudichaudiic acid & G. lateriflora & HT-29 & $3.2^{\mathrm{a}}$ & {$[16]$} \\
\hline 35 & Garcibractatin A & G. bracteata & $\begin{array}{l}\text { A549 } \\
\text { HeLa } \\
\text { HT-29 } \\
\text { PC-3 } \\
\text { WPMY-1 }\end{array}$ & $\begin{array}{l}2.0 \\
2.6 \\
1.1 \\
2.9 \\
0.8\end{array}$ & [21] \\
\hline 36 & 16,17-Dihydroxygambogenic acid & G. hanburyic & $\begin{array}{l}\text { HeLa } \\
\text { MDA-MB-231 }\end{array}$ & $\begin{array}{l}4.3 \\
2.1\end{array}$ & [32] \\
\hline 37 & 22,23-Dihydroxydihydrogambogenic acid & G. hanburyi & $\begin{array}{l}\text { A549 } \\
\text { HCT-116 } \\
\text { MDA-MB-231 }\end{array}$ & $\begin{array}{l}5.0 \\
0.7 \\
2.7\end{array}$ & {$[25]$} \\
\hline 38 & Garcioligantone A or oliganthone C & G. oligantha & $\begin{array}{l}\text { A549 } \\
\text { HeLa } \\
\text { PC-3 }\end{array}$ & $\begin{array}{l}5.3 \\
2.7 \\
2.5\end{array}$ & {$[18,22]$} \\
\hline 39 & Garcioligantone B & G. oligantha & - & - & [18] \\
\hline 40 & Garcioligantone I & G. oligantha & - & - & [18] \\
\hline 41 & Garcioligantone J & G. oligantha & $\begin{array}{l}\text { A549 } \\
\text { HeLa } \\
\text { PC-3 }\end{array}$ & $\begin{array}{l}5.9 \\
3.7 \\
3.4\end{array}$ & [18] \\
\hline 42 & Garcioligantone K & G. oligantha & $\begin{array}{l}\text { HeLa } \\
\text { PC-3 }\end{array}$ & $\begin{array}{l}2.6 \\
2.8\end{array}$ & {$[18]$} \\
\hline 43 & Garcioligantone L & G. oligantha & $\begin{array}{l}\text { A549 } \\
\text { HeLa } \\
\text { K562 }\end{array}$ & $\begin{array}{l}4.5 \\
3.0 \\
2.5\end{array}$ & [18] \\
\hline 44 & Oliganthone D & G. oligantha & - & - & {$[22]$} \\
\hline 45 & Oliganthone F & G. oligantha & - & - & [22] \\
\hline 46 & Gamboketanol & G. hanburyi & HeLa & 3.8 & {$[24]$} \\
\hline 47 & 8,8a-Dihydro-8-hydroxymorellic acid & G. hanburyi & HeLa & 1.7 & [15] \\
\hline
\end{tabular}


Acta

Materia

Medica

Table 1 | Continued

\begin{tabular}{|c|c|}
\hline & Compound \\
\hline 48 & $10 \alpha$-Ethoxy-9,10-dihydromorellic acid \\
\hline 49 & 8,8a-Dihydro-8-hydroxygambogic acid \\
\hline 50 & 8,8a-Dihydro-8-hydroxygambogic acid epimer \\
\hline 51 & Gambogic acid A \\
\hline 52 & Epigambogic acid $\mathrm{A}$ \\
\hline 53 & Gambogic acid B \\
\hline 54 & Epigambogic acid B \\
\hline 55 & $10 \alpha$-Butoxy gambogic acid \\
\hline 56 & Isomoreollic acid \\
\hline 57 & Methyl 8,8a-dihydromorellate \\
\hline 58 & Garcinolic acid \\
\hline
\end{tabular}

Source

G. hanburyi

G. hanburyi

G. hanburyi

G. hanburyi

G. hanburyi

G. hanburyi

G. hanburyi

G. hanburyi

G. lateriflora

G. hanburyi

G. hanburyi

G. propinqua

G. hanburyi

G. hanburyi

G. propinqua

G. propinqua

G. propinqua

G. propinqua

G. bracteata

G. bracteata

G. propinqua

G. bracteata

G. hanburyi

G. hanburyi

G. oligantha

G. oligantha

G. oligantha

G. oligantha

G. bracteata

G. bracteata

G. bracteata

G. bracteata

Cell lines

$\begin{array}{ll}\text { A549 } & 4.9 \\ \text { HCT-116 } & 1.7 \\ \text { HepG2 } & 2.1 \\ \text { SK-BR-3 } & 2.2 \\ \text { HeLa } & 0.64 \\ \text { HeLa } & 0.63 \\ - & - \\ - & - \\ - & - \\ - & - \\ - & - \\ \text { HT-29 } & 1.9 \\ - & - \\ \text { A549 } & 2.8 \\ \text { HCT-116 } & 1.8 \\ \text { HepG2 } & 1.8 \\ \text { SK-BR-3 } & 1.9\end{array}$

$I_{50}(\mu \mathrm{M}) \quad$ Ref.

[33]

$\begin{array}{ll}\text { A549 } & 3.2\end{array}$

HCT-116 2.0

MDA-MB-231 0.5

[18]

$\begin{array}{ll}\mathrm{HL}-60 & 4.5^{\mathrm{b}} \\ \mathrm{K} 562 & 2.1^{\mathrm{b}}\end{array}$

[28] 
Table 1 | Continued

\begin{tabular}{|c|c|c|c|c|c|}
\hline & Compound & Source & Cell lines & $\mathrm{IC}_{50}(\mu \mathrm{M})$ & Ref. \\
\hline 80 & Doitunggarcinone $\mathrm{E}$ & G. propinqua & - & - & {$[27]$} \\
\hline 81 & Gambospiroene & G. hanburyi & - & - & {$[15]$} \\
\hline 82 & Neobractatin & $\begin{array}{l}\text { G. propinqua, } \\
\text { G. bracteata }\end{array}$ & $\begin{array}{l}\text { A549 } \\
\text { HeLa } \\
\text { HL-60 } \\
\text { HT-29 } \\
\text { K562 } \\
\text { MCF-7 } \\
\text { PC-3 } \\
\text { SMMC-7721 } \\
\text { SW480 } \\
\text { WPMY-1 }\end{array}$ & $\begin{array}{l}1.5,3.5 \\
0.9 \\
0.8^{b}, 3.3 \\
3.8^{-} \\
1.3^{b} \\
2.2 \\
2.9 \\
4.3 \\
2.8 \\
2.1\end{array}$ & $\begin{array}{l}{[29-31,} \\
35]\end{array}$ \\
\hline 83 & 3-O-methylneobractatin & $\begin{array}{l}\text { G. propinqua, } \\
\text { G. bracteata }\end{array}$ & $\begin{array}{l}\text { HL-60 } \\
\text { HT-29 } \\
\text { MCF-7 } \\
\text { PC-3 } \\
\text { SMMC-7721 } \\
\text { SW480 } \\
\text { WPMY-1 }\end{array}$ & $\begin{array}{l}2.9 \\
3.4 \\
1.9 \\
4.5 \\
3.9 \\
2.8 \\
1.8\end{array}$ & [29-31] \\
\hline 84 & 8-Methoxy-8,8a-dihydroneobractatin & G. bracteata & K562 & $3.5^{b}$ & [20] \\
\hline 85 & Neogaudichaudione $\mathrm{H}$ & G. oligantha & - & - & [18] \\
\hline 86 & Garcineobractatin A & G. bracteata & - & - & [21] \\
\hline 87 & Neobraclactone A & G. bracteata & $\begin{array}{l}\mathrm{HL}-60 \\
\mathrm{~K} 562\end{array}$ & $\begin{array}{l}0.50^{b} \\
0.40^{b}\end{array}$ & [36] \\
\hline 88 & Neobraclactone B & G. bracteata & $\begin{array}{l}\mathrm{HL}-60 \\
\mathrm{~K} 562\end{array}$ & $\begin{array}{l}0.50^{b} \\
0.86^{b}\end{array}$ & [36] \\
\hline 89 & Neobraclactone C & G. bracteata & - & - & [36] \\
\hline 90 & Cochinchinoxanthone A & C. cochinchinense & - & - & [37] \\
\hline 91 & Cochinchinoxanthone B & C. cochinchinense & - & - & [37] \\
\hline 92 & Cochinchinoxanthone D & C. cochinchinense & - & - & [37] \\
\hline 93 & Cochinchinoxanthone & $\begin{array}{l}\text { C. cochinchinense, } \\
\text { G. bracteata }\end{array}$ & $\begin{array}{l}\text { HT-29 } \\
\text { PC-3 } \\
\text { WPMY-1 }\end{array}$ & $\begin{array}{l}3.1 \\
4.8 \\
3.1\end{array}$ & {$[21,38]$} \\
\hline 94 & Cochinchinoxanthone C & C. cochinchinense & - & - & [37] \\
\hline 95 & Pruniflorone U & C. formosum & - & - & [39] \\
\hline 96 & Pruniflorone T & C. formosum & - & - & [39] \\
\hline
\end{tabular}

${ }^{*}$ Cytotoxicities with $\mathrm{IC}_{50} \geq 5 \mu \mathrm{M}$ are not listed.

${ }^{a} E D_{50}$ (in $\mu \mathrm{M}$ ) was recorded.

${ }^{\mathrm{b}} \mathrm{GI}{ }_{50}$ (in $\mu \mathrm{M}$ ) was recorded.

cFrom microbial transformation of gambogenic acid (isolated from G. hanburyi).

\section{STRUCTURAL DIVERSITY OF CAGED GARCINIA XANTHONES}

The complex and unusual chemical architectures of caged xanthones have been attractive to chemists worldwide. Salient features of compounds belonging to this group of natural products include a common xanthone backbone with a $D$ ring transformed into a unique 4-oxa-tricyclo[4.3.1.0 $\left.0^{3,7}\right]$ dec-2-one (caged) scaffold embedded with a highly substituted tetrahydrofuran core bearing three quaternary carbon centers (Figure 1). The $B$ ring is typically a benzene ring substituted with hydroxyl and $\mathrm{R}$ groups $(\mathrm{H}$, methyl or substituents shown in Figure 2) in various positions. Prenylation 


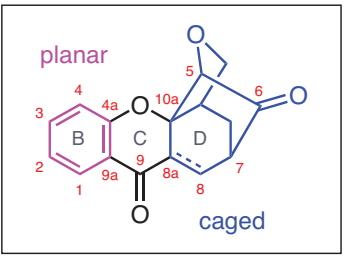

caged Garcinia xanthone

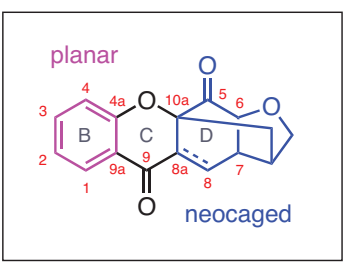

neocaged Garcinia xanthone

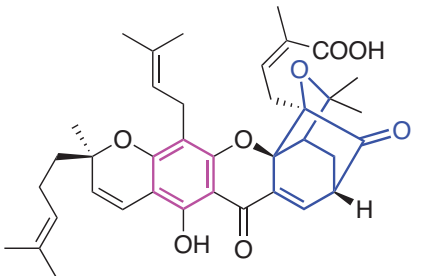

gambogic acid

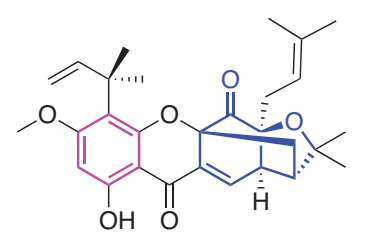

neobractatin variations of $A$ and $B$ rings<smiles>[R]c1ccc(O)c2c1OC([R])([R])C=C2</smiles><smiles>[R]c1ccc(O)c([R])c1[R]</smiles><smiles>[R]c1cc2ccccc2o1</smiles><smiles>[R]C1([R])C=Cc2ccccc2O1</smiles><smiles>[R]CCC1c2c(O)ccc([R])c2OC([R])([R])C1CC[R]</smiles><smiles>[R]c1ccc(O)c2c1OC1([R])CCC([R])C2C1</smiles>

Figure 1 | Molecular skeletons of caged and neocaged Garcinia xanthones.

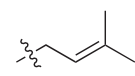

IPL:

isoprenyl

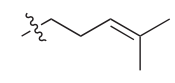

HPL: homoprenyl

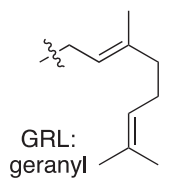

geranyl

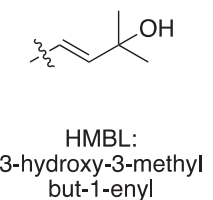

but-1-enyl
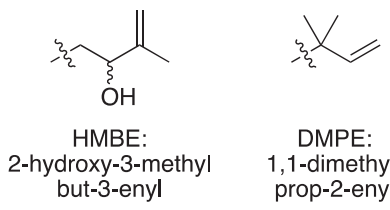

DMPE:

1,1-dimethylprop-2-enyl

Figure 2 | Structures and abbreviations of side chains

or geranylation of $\mathrm{B}$ rings produces bi- or tricyclic ring systems upon cyclization reaction. The D ring, in contrast, also has variable substituents with or without a double bond at the C-8/8a position. Together, the structural variability in $A, B$ and $D$ ring systems leads to diverse skeletons of caged xanthones, as shown by the chemical structure of gambogic acid.

Although most caged xanthones possess the 4-oxatricyclo[4.3.1.0 $\left.0^{3,7}\right]$ dec-2-one skeleton, few compounds with a rearranged caged backbone, known as neocaged compounds, have been reported (Figure 1). A representative compound from this class is neobractatin. Similarly, different substituents on $B$ and $D$ rings contribute to the structural diversity of these compounds. The structures of side chains and the abbreviations used herein are illustrated in Figure 2.

\subsection{Caged xanthones with $\Delta^{8 / 8 a}$ on the $\mathrm{D}$ ring}

\subsubsection{Presence of the $A$ ring}

Caged xanthones with an $A$ ring and $\Delta^{8 / 8 a}$ on the $D$ ring comprise 29 new members (1-29, Figure 3) from the year 2008 to the present. Compounds $\mathbf{1}$ and 3-5 are four derivatives of gambogic acid isolated from the resin of G. hanburyi $[14,15]$. Among them, gambogic aldehyde (1) has the same skeleton as gambogic acid (Figure 1), except that the - $\mathrm{COOH}$ group of gambogic acid is substituted by -CHO. A pair of epimers, 7-methoxygambogic acid $(3,13 R)$ and 7-methoxyepigambogic acid (4, 13S), possess a methoxy group at C-7, whereas oxygambogic acid (5) is characterized by a 3-hydroxy-3-metylbut-1enyl instead of prenyl $\mathrm{R}^{1}$ substituent. The compound 7-methoxyisomorellinol (2), bearing an additional C-7 methoxy group, as compared with its parent compound, isomorellinol, has also been found in G. hanburyi [15]. Isolated from G. lateriflora, 11,12-dihydro-12-hydroxymorellic acid (6) features a hydroxy group at C-12 whose absolute configuration remains undefined, because of the limited quantity of the compound available, whereas isogaudichaudiic acid E (7) exhibits a 2-hydroxy3-methylbut-3-enyl group at C-4 and an (E)-C-22/C-23 double bond [16]. Investigations on G. wightii, a species native to India, have led to the isolation of wightiic acid (8) and 16-O-methyl wightiic acid (9) from its leaves [17]. Both bear an unusual C-4 epoxy butyl group and C-5 cycloprop-2-enyl moiety.

In addition, 13 caged xanthones (10-22) bear an $A$ ring on $\mathrm{C}-3 / \mathrm{C}-4$ instead of $\mathrm{C}-2 / \mathrm{C}-3$. Garcioligantones $\mathrm{G}$ (10), $H(11)$ and oliganthone B (12) from twigs of $G$. oligantha are three examples of C-7 methoxylated caged xanthones with a pyran A ring $[18,19]$. Another six compounds, epiisobractatin (13), 13-hydroxyepiisobractatin $(14,12 S)$ and 13-hydroxyisobractatin (15, $12 R)$ from $G$. bracteata $[20,21]$; epicantleyanone B (16) and 11-methoxyepicantleyanone B (17) from G. oligantha [18]; and gambogenific acid (22) from G. hanburyi $[15,23]$, represent novel caged xanthones with 


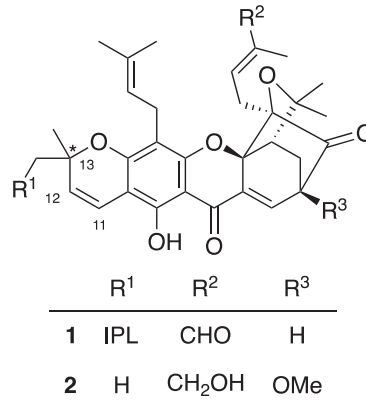

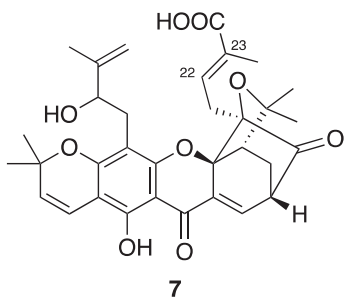

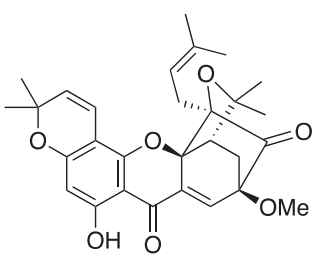

12

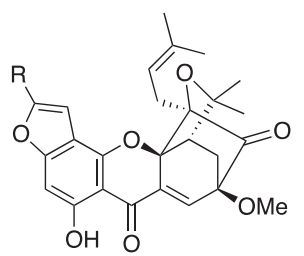<smiles>C=C(C)C=[R]OCC(C)(C)C=[18O]</smiles>
$19 \mathrm{R}=\xi_{2} \mathrm{~K}_{2} \mathrm{OH} \quad 21 \mathrm{R}=\mathrm{H}$

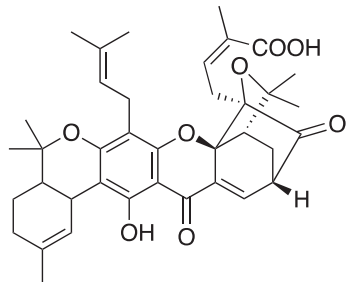

25

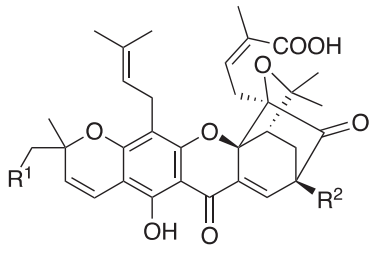

$3 / 4 \mathrm{R}^{1}=\mathrm{IPL} ; \quad \mathrm{R}^{2}=\mathrm{OMe}$ $5 \mathrm{R}^{1}=\mathrm{HMBL} ; \mathrm{R}^{2}=\mathrm{H}$

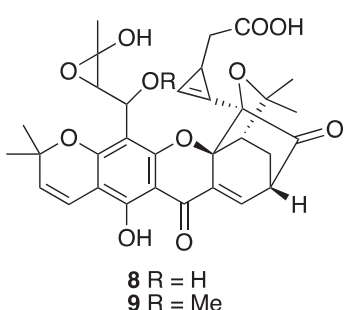

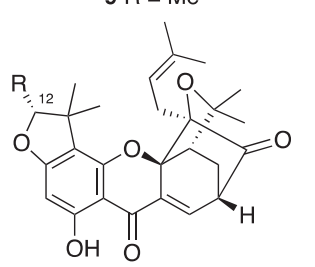

$$
13 \mathrm{R}=\mathrm{Me}
$$

14/15 $\mathrm{R}=\mathrm{CH}_{2} \mathrm{OH}$

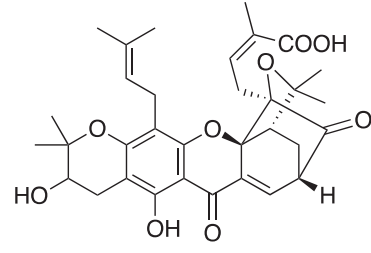

6

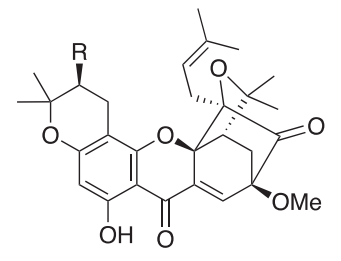

$10 \mathrm{R}=\mathrm{H}$

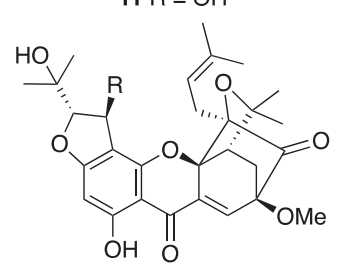

$16 \mathrm{R}=\mathrm{H}$

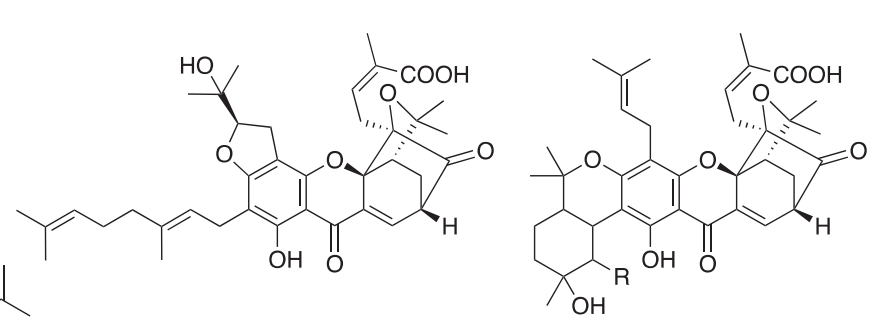

22

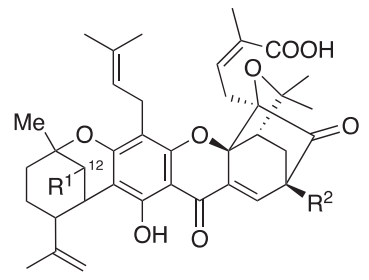

$26 \mathrm{R}^{1}=\mathrm{H} ; \quad \mathrm{R}^{2}=\mathrm{OMe}$
$23 \mathrm{R}=\mathrm{H}$
$24 \mathrm{R}=\mathrm{OH}$

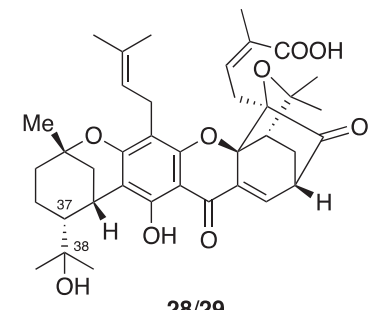

$28 / 29$

Figure 3 | Structures of caged xanthones with $\Delta^{8 / 8 a}$ and an A ring.

a multisubstituted dihydrofuran unit as the $A$ ring. Compounds 16 and 17 are 7-methoxylated, whereas 22 bears a geranyl moiety at C-2 and carboxylic acid functionality at C-5. Related compounds with a furan skeleton instead of dihydrofuran have been observed in garcioligantones C-F (18-21) [18]. Notably, garcioligantone $F(21)$ has also been reported by another research group but given a different name: oliganthone E [22]. The other compounds, 23-25 from G. hanburyi, present a fused bicyclic ring attached to the caged xanthone skeleton in which gambogefic acid A (23) [24] and 12-hydroxygambogefic acid A (24) [25] are the hydrated and dihydroxylated version of gambogefic acid (25) [15], respectively. Beyond gambogellic acid, 
which was discovered and isolated in 1996 [62], another three compounds (26-29) bearing a rare bridged bicyclic A ring system have been found. The compound 7-methoxygambogellic acid (26) has a methoxy moiety substituted at C-7 [18]; gambogellic acid A (27) is 12-hydroxylated [24] and gambogollic acid (28) and its epimer (29) are oxidized at C-38, with 28 bearing $\beta-\mathrm{H}$ at $\mathrm{C}-37$ and 29 bearing $\alpha-\mathrm{H}[26]$.

\subsubsection{Absence of the $A$ ring}

Since 2008, 17 caged xanthones (30-46, Figure 4) with $\Delta^{8 / 8 a}$ but not an $A$ ring have been isolated and identified. The structural diversity of these compounds lies mainly in the different substitutions at the C-2, C-4 and C-5 positions. Doitunggarcinone K (30) [27, 28], 3-O-geranylforbesione (31) [15], 3-O-methylbractatin (32) [29-31] and garcibractatin A (35) [21] are alkoxylated at C-3. Compounds 32 and 35 possess exactly the same chemical structure, except that the C-1 hydroxyl is replaced by -OMe in 35 . Isogaudichaudiic acid B (33) and isogaudichaudiic acid (34), obtained from G. lateriflora, have a C-2 prenyl unit and two phenolic hydroxyls [16]. Two dihydroxylated derivatives of gambogenic acid, 16,17-dihydroxygambogenic acid (36) [32] and 22,23-dihydroxydihydrogambogenic acid (37) [25], display a characteristic C-2 dihydroxylated geranyl and C-4 dihydroxylated prenyl group, respectively. Another eight 7-methoxylated caged xanthones (38-45) from G. oligantha contain oxidized C-4 or C-5 substituents [18]. Structurally, the 3-hydroxy-3-methylbut-1-enyl group at $\mathrm{C}-5$ is observed for garcioligantones $A$ (38, repeatedly reported but named oliganthone $C$ [22]) and B (39), whereas the prenyl moiety is shown for garcioligantones I-L (40-43) and oliganthones D (44), F (45).

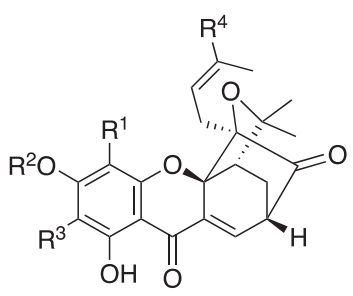

\begin{tabular}{ccccc} 
& $\mathrm{R}^{1}$ & $\mathrm{R}^{2}$ & $\mathrm{R}^{3}$ & $\mathrm{R}^{4}$ \\
\hline $\mathbf{3 0}$ & $\mathrm{H}$ & $\mathrm{IPL}$ & $\mathrm{H}$ & $\mathrm{Me}$ \\
$\mathbf{3 1}$ & $\mathrm{IPL}$ & $\mathrm{GRL}$ & $\mathrm{H}$ & $\mathrm{Me}$ \\
$\mathbf{3 2}$ & $\mathrm{DMPE}$ & $\mathrm{Me}$ & $\mathrm{H}$ & $\mathrm{Me}$ \\
$\mathbf{3 3}$ & $\mathrm{HMBE}$ & $\mathrm{H}$ & $\mathrm{IPL}$ & $\mathrm{COOH}$ \\
$\mathbf{3 4}$ & $\mathrm{IPL}$ & $\mathrm{H}$ & $\mathrm{IPL}$ & $\mathrm{COOH}$
\end{tabular}<smiles>C=CC(C)(C)c1c(OC)cc(OC)c2c1O[C@]13CC[C@H](C=C1C(=O)C2)[C@](CC=C(C)C)(C(C)(C)C)O3</smiles>

35

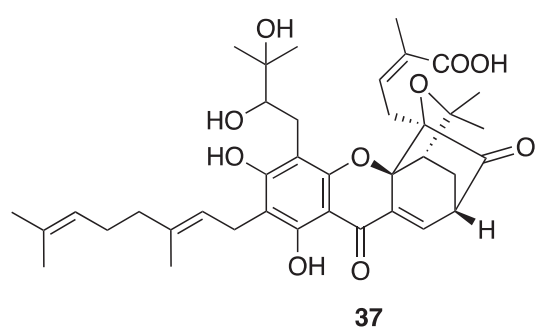

36<smiles>COC12C=C3C(=O)c4c(O)cc(O)c(CC=C(C)C)c4OC3(CC1)C(C=CC(C)(C)O)OC2(C)C</smiles>

38<smiles>C=C(C)[C@H](O)Cc1c(O)cc(O)c2c1O[C@]13CCC(C)(C=C1C(=O)C2(C)C)OC3(C)C</smiles>

39<smiles>[R]c1c(O)cc(O)c2c1O[C@]13CCC(OC)(C=C1C(=O)C2(C)C)C(C)(C)O3</smiles>

$\begin{array}{ll}40 & R \\ 41 / 42 & =\mathrm{CHO} \\ \mathrm{R} & =\mathrm{HMBE}\end{array}$<smiles>COC12C=C3C(=O)c4c(O)cc(O)c(C/C=C(\C)CO)c4OC3(CC1)C(CC=C(C)C)C(=O)C2(C)C</smiles>

43

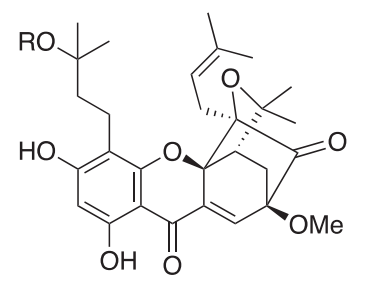

$44 \mathrm{R}=\mathrm{Me}$
$45 \mathrm{R}=\mathrm{Ac}$

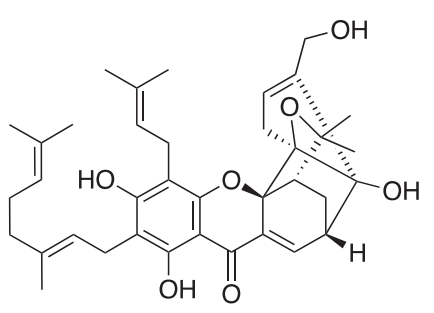

46

Figure 4 | Structures of caged xanthones with $\Delta^{8 / 8 a}$ but without an A ring. 
Gamboketanol (46) from G. hanburyi is a rarely found pentaprenylxanthonoid likely to arise from decarboxylation and rearrangement of gambogenic acid [24] Additional cyclization forms between the C-5 side chain and C-6 carbonyl group.

\subsection{Caged xanthones without $\Delta^{8 / 8 a}$ on the $D$ ring 2.2.1 Presence of an A ring}

Detailed phytochemical investigations of Garcinia plants have identified several caged xanthones (47-61, Figure 5) with a hydroxyl or alkoxy group attached at the C-8 position. The compounds 8,8a-dihydro-8-hydroxymorellic acid (47) [15] and 10 $\alpha$-ethoxy-9,10-dihydromorellic acid (48) [33] exhibit a dimethyl substitution at the C-13 and C-8 hydroxyl in $\mathbf{4 7}$ but at the C-8 ethoxy group in 48. Instead of a dimethyl, one of the methyl groups at $\mathrm{C}-13$ is substituted with a homoprenyl side chain in compounds 49-55, namely 8,8a-dihydro-8-hydroxygambogic acid and epimer (49/50) [15], gambogic acid $A$ and epimer (51/52), gambogic acid B and epimer (53/54), as well as 10 -butoxygambogic acid (55) [34]. Accordingly, their C-8 positions are substituted by hydroxyl, methoxy,

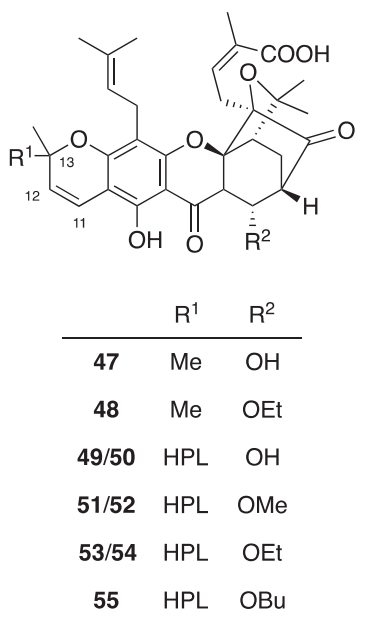

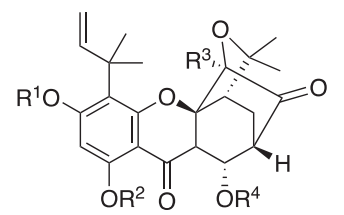

\begin{tabular}{ccccc} 
& $\mathrm{R}^{1}$ & $\mathrm{R}^{2}$ & $\mathrm{R}^{3}$ & $\mathrm{R}^{4}$ \\
\hline 62 & $\mathrm{Me}$ & $\mathrm{H}$ & $\mathrm{IPL}$ & $\mathrm{Me}$ \\
63 & $\mathrm{Me}$ & $\mathrm{H}$ & $\mathrm{HMBL}$ & $\mathrm{Me}$
\end{tabular}

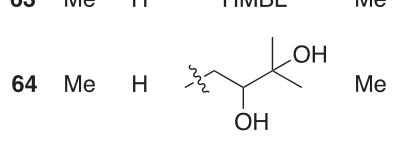

$\begin{array}{ccccc}65 & M e & H & \text { HMBE } & \text { Me } \\ 66^{\prime} & \text { H } & \text { H } & \text { HMBL } & \text { Me } \\ 67 & H & H & \text { IPL } & H \\ 68 & H & H & \text { IPL } & M e \\ 69 & M e & M e & \text { IPL } & \text { Et }\end{array}$

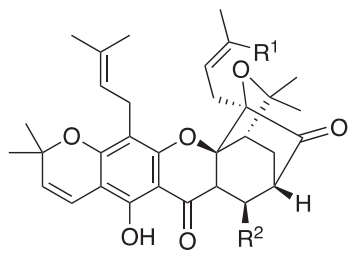

$56 \mathrm{R}^{1}=\mathrm{COOH} ; \mathrm{R}^{2}=\mathrm{OMe}$ $57 \mathrm{R}^{1}=\mathrm{COOMe} ; \mathrm{R}^{2}=\mathrm{H}$

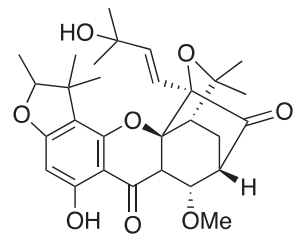

59

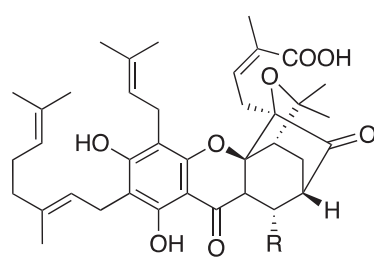

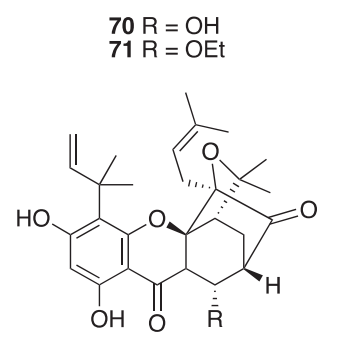

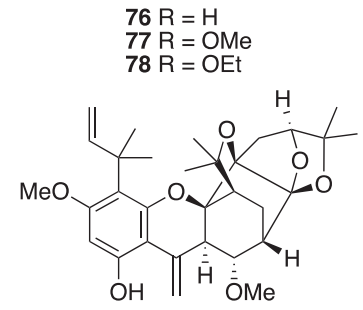

80

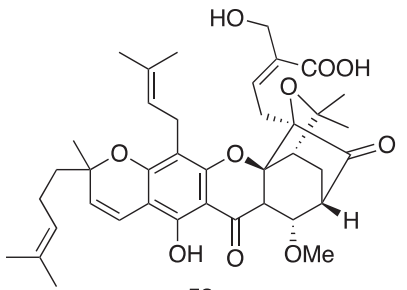

58

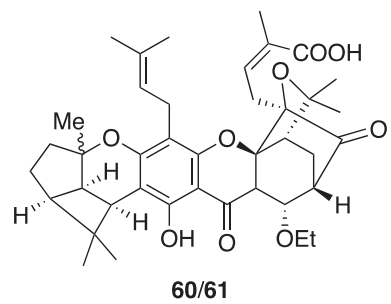

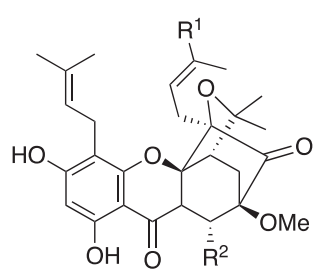

$$
\begin{array}{rlrl}
72 \mathrm{R}^{1} & =\mathrm{Me} ; & \mathrm{R}^{2} & =\mathrm{H} \\
73 \mathrm{R}^{1} & =\mathrm{CH}_{2} \mathrm{OAc} ; \mathrm{R}^{2}=\mathrm{H} \\
74 \mathrm{R}^{1} & =\mathrm{Me} ; & \mathrm{R}^{2} & =\mathrm{OH} \\
75 \mathrm{R}^{1} & =\mathrm{Me} ; & \mathrm{R}^{2} & =\mathrm{OEt}
\end{array}
$$

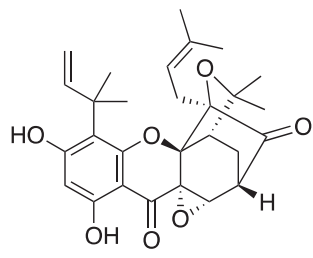<smiles>CC(C)=CCCC(C)=CCc1c(O)c(CC=C(C)C)c2c(c1O)C(=O)C1C=CCC3C(=O)OC4(CC=CC4=O)C2(O1)OC3(C)C</smiles>

81

Figure 5 | Structures of caged xanthones without $\Delta^{8 / 8 a}$. 
ethoxy or butoxy groups. Isomoreollic acid (56) features a dihydropyran A ring, C-8 methoxy moiety and (Z)-2methylbut-2-enoic acid at C-5 [16]. Compared with 56, C-8 of methyl-8,8a-dihydromorellate (57) is not substituted, and the carboxylic acid is replaced by methyl ester functionality [15]. Isolated from the ethyl acetate extract of the resin of G. hanburyi, garcinolic acid (58) is highly similar to $\mathbf{5 1 / 5 2}$, except for an oxidized C-5 group [33]. The structure of doitunggarcinone J (59) bears a trimethylated dihydrofuran A ring, C-8 methoxy group and C-5 3-hydroxy-3-metylbut-1-enyl side chain [27]. The novel gambogic acid $\mathrm{C}(\mathbf{6 0}, \alpha-\mathrm{Me})$ and epimer $(61, \beta-\mathrm{Me})$ from $G$. hanburyi have two additional ring systems on the molecular scaffold [34].

\subsubsection{Absence of an A ring}

Twenty caged xanthones (62-81, Figure 5) without $\Delta^{8 / 8 a}$ and an A ring have been obtained from Garcinia genus since 2008. Doitunggarcinones F-I (62-65), obtained from the stem bark extract of $G$. propinqua, possess two methoxy groups and a phenolic hydroxyl group with a different C-5 moiety [27]. In contrast, garcibracteatone' (66') [20] and doitunggarcinone L (68) [30] have only one methoxy group but two phenolic hydroxyl groups. The name of garcibracteatone is somewhat confusing, because it represents two different compounds with entirely different molecular skeletons (Figure 6) [20,63]. Garcibracteatone (66) was first isolated from the bark of $G$. bracteata in 2005 [63] and from the fruits of the same plant in 2020 [64]. Its biomimetic total synthesis was reported by the George research group in 2012 [65], and enantioselective total synthesis was reported in 2014 [66]. An unprecedented cage xanthone, compound $\mathbf{6 6}^{\prime}$, isolated from the leaves of $G$. bracteata, was also named garcibracteatone (designated garcibracteatone' herein) by Li and Hua in 2018 [20]. Compared with 68, garcibractone A (67) bears a hydroxyl group at C-8 instead of -OMe [21], whereas garcibractone B (69) has two methoxy groups at C-1 and C-3 and an ethoxy side chain at C-8.

Compounds 70 and 71 are two C-8 derivatives of gambogenic acid with a hydroxyl or ethoxy side chain at C-8 $[15,33]$. The compound 8,8a-dihydrogaudichaudione

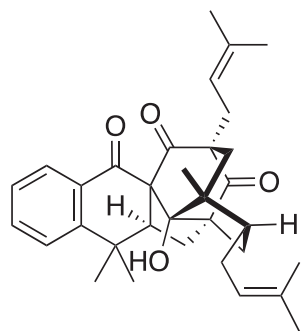

$$
\mathrm{C}_{33} \mathrm{H}_{40} \mathrm{O}_{4}
$$

$\mathrm{MW}=500.68$ garcibracteatone (66)

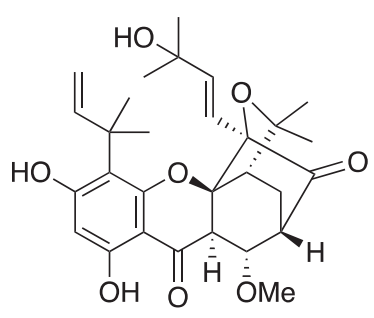

garcibracteatone' $\left(6^{\prime}\right)$

$$
\mathrm{C}_{29} \mathrm{H}_{36} \mathrm{O}_{8}
$$

$\mathrm{MW}=512.60$
Figure 6 | Chemical structures of two garcibracteatones.
$H(72)$, isolated from G. oligantha, is methoxylated at the C-7 position [18]. Xanthones 73-75 are the acetoxylated, hydroxylated or ethoxylated derivatives of $\mathbf{7 2}$, respectively, and were found from the same species [18]. Isolated from G. bracteata, garcibracteamone F (76) is reduced at C-8/C-8a, whereas garcibracteamone G (79) is epoxidized at C-8/C-8a [28]. The compounds 8-methoxy-8,8a-dihydrobractatin and 8-ethoxy-8,8a-dihydrobractatin (77 and 78) differ from 76 only in the substituent at C-8 [20]. The chemical structure of doitunggarcinone $E(\mathbf{8 0})$ is presumably formed from dihydroxylation of the C-5 prenyl moiety, followed by intramolecular ketal formation to yield additional fused $5 / 6$ rings [27]. A degraded and rearranged caged xanthone scaffold has been observed in gambospiroene (81) from G. hanburyi [15].

\subsection{Neocaged xanthones}

Xanthones with the neo scaffold have the ketone carbonyl group at C-5 instead of C-6, as observed in the classic caged xanthones. Only five natural compounds (82-86) from this classification have been isolated in the described period, along with three rearranged structures (87-89) (Figure 7). In continued efforts to search for bioactive components from tropical plants, two novel compounds (82-83) with a neocaged structure have been found from twigs of G. bracteata and G. propinqua [29$31,35]$. As the name implies, 3-O-methylneobractatin (83) bears an -OMe substituent at C-3, as compared with neobractatin (82); whereas 8-methoxy-8,8a-dihydroneobractatin (84) has the -OMe at the C-8 position instead [20]. Neogaudichaudione $\mathrm{H}$ (85) bears a prenyl group at C-4 and a methoxy group at C-7 [18]. The structure of garcineobractatin A (86) is highly similar to that of neobractatin, except for an unsubstituted C-4 and a prenyl side chain at C-2 [21]. The unusual rearrangement of the neo skeleton leads to neobraclactones A-C (87-89) from $G$. bracteata [36]. They share a common octahydro-2H-1,3-dioxacyclopenta[c, $d$ ] inden-2-one framework; however, additional cyclization is observed in $\mathbf{8 9}$.

\subsection{Caged xanthones of non-Garcinia origin}

Beyond compounds from Garcinia, caged and neocaged xanthones (90-96, Figure 7) are also found in the Cratoxylum plant. Cochinchinoxanthone A (90) from Cratoxylum cochinchinense contains a simple caged skeleton with a methoxy group at C-7 [37]. Cochinchinoxanthones B (91) and D (92) are also substituted with $8 \mathrm{a}-\mathrm{OH}$ and $8-\mathrm{OMe}$, respectively. Compared with 90, cochinchinoxanthone (93) has an unsubstituted $\mathrm{C}-7$, a double bond between $\mathrm{C} 8$ and C-8a and an additional C-3 hydroxyl group [38]. Cochinchinoxanthone C (94) contains a C-8-OMe group with a different relative configuration from that of $\mathbf{9 2}$. Moreover, pruniflorone $U$ (95) is an uncommon example of a caged xanthone isolated from the roots of $C$. formosum ssp. pruniflorum [39]. It is an unprecedented ring-cleaved, rearranged caged xanthone with bond breakage at C-6/C-7. In 


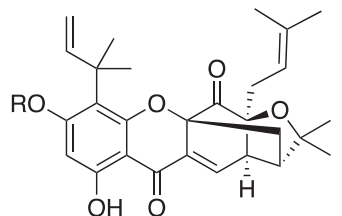

$82 \mathrm{R}=\mathrm{H}$ $83 \mathrm{R}=\mathrm{Me}$

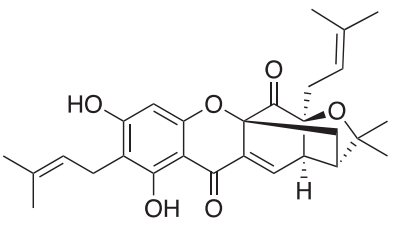

86

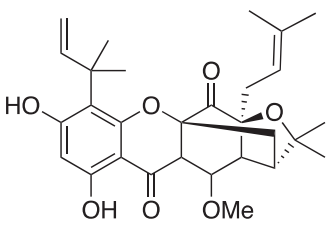

84<smiles>C=CC(C)(C)c1c(O)cc(O)c2c(=O)c3c(oc12)CC1C2O[C@@]1(CC(O)C(=C)C)C(=O)O[C@@H]2C(C)(C)O3</smiles>

$87 / 88$

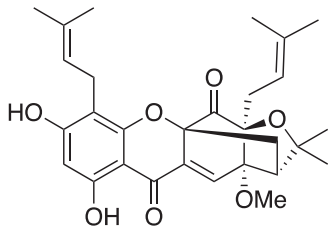

85

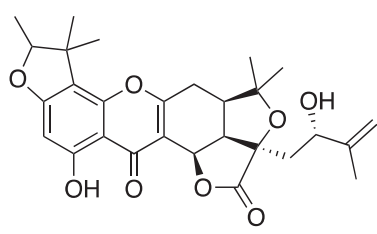

89

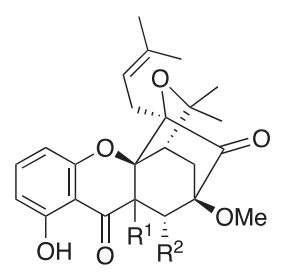

$90 \mathrm{R}^{1}=\mathrm{H} ; \mathrm{R}^{2}=\mathrm{H}$ $91 \mathrm{R}^{1}=\mathrm{OH} ; \mathrm{R}^{2}=\mathrm{H}$ $92 \mathrm{R}^{1}=\mathrm{H} ; \quad \mathrm{R}^{2}=\mathrm{OMe}$

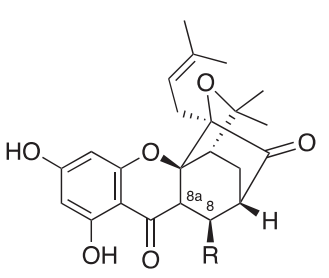

$93 \Delta^{8 / 8 a}$

$94 \mathrm{R}=\mathrm{OMe}$

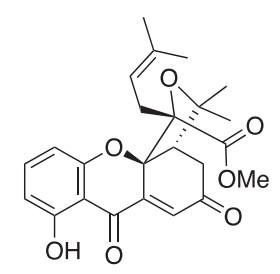

95

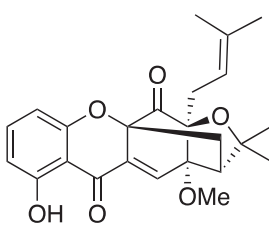

96

Figure 7 | Structures of neocaged and non-Garcinia caged xanthones.

addition, pruniflorone $\mathrm{T}$ (96), reported from C. formosum, bears a neocaged scaffold similar to that of 85 but does not have substituents at C-3 and C-4 [39].

\section{BIOLOGICAL ACTIVITIES AND MECHANISMS}

Beyond structural diversity, the promising biological activities of caged xanthones have made these compounds a prominent subject in the discovery and development of lead compounds, particularly as anticancer drugs. Over the past two decades, a vast number of caged xanthones have been subjected to cancer cell line screening. Close attention has been paid to several compounds with potent anticancer effects, such as neobractatin (82), gambogic acid (97), gambogenic acid (100), isomorellin (101) and forbesione (103) (Figure 8). Herein, the bioactivities and the mechanisms of action of these natural compounds are summarized and reviewed, along with the noteworthy derivatives of gambogic acid cluvenone (98) and DDO6101 (99, also known as MAD28).

\subsection{Anticancer activities}

\subsubsection{General properties}

The cytotoxicity and effects of many caged xanthones have been tested against multiple human cancer cell lines in the past decade. Frequently, the cytotoxicity of these compounds has been assessed against A549 human lung carcinoma and HeLa human cervical carcinoma cell lines. Very recently, a total of nine 7-methoxylated caged xanthones (10, 16, 19, 21, 38, 41-43 and 72) have demonstrated promising cytotoxicity $\left(\mathrm{IC}_{50}<8 \mu \mathrm{M}\right)$ against A549, HeLa and human prostate cancer PC-3 cell lines [18]. The other two compounds, 18 and 20, also display good activity against HeLa cells, at $\mathrm{IC}_{50}=3.6$ and $5.9 \mu \mathrm{M}$, respectively. Many caged xanthones including 35, 67-69, $(-)-78,82,83,86,93$, bractatin, 1-O-methylbractatin, isobractatin, 1-O-methylisobractatin, epiisobractatin and isoforbesione have also been tested against A549, HeLa, human colon adenocarcinoma HT-29, human prostate cancer PC-3 and WPMY-1 cell lines [21, 67]. The results have indicated that 67,69 and 86 are inactive against all cell lines $\left(\mathrm{IC}_{50}>10 \mu \mathrm{M}\right) ; \mathbf{6 8},(-)-78$ and 1-O-methylbractatin are active against only two or three cell lines, and the rest are cytotoxic $\left(\mathrm{IC}_{50}<10 \mu \mathrm{M}\right)$ in all cell lines. Mechanistically, the antiproliferative effect of isobractatin against PC-3 is caused by G0/G1 cell cycle arrest and apoptosis induction [67].

Furthermore, ten compounds (22, desoxymorellin, desoxygambogenin, gambogenin, isogambogenin, isogambogic acid, isogambogenic acid, morellic acid, a mixture of morellin and an inseparable regioisomer) are cytotoxic against four cancer cell lines (A549, HeLa, human colorectal carcinoma HCT116 and human hepatocellular carcinoma HepG2 cells), with $\mathrm{IC}_{50}$ ranging from 0.64 to $14.23 \mu \mathrm{M}$; moreover, all show potent 


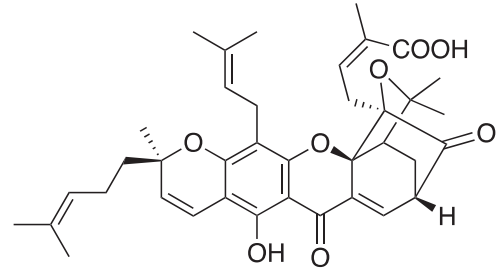

gambogic acid (97)

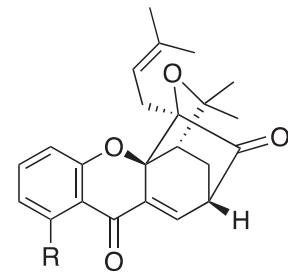

cluvenone (98) $\mathrm{R}=\mathrm{H}$ DDO 6101 (99) $\mathrm{R}=\mathrm{OH}$

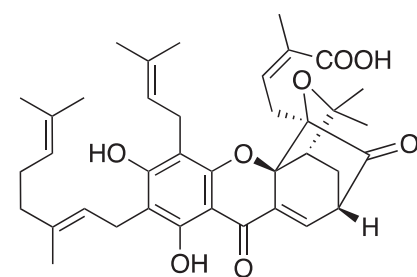

gambogenic acid (100)

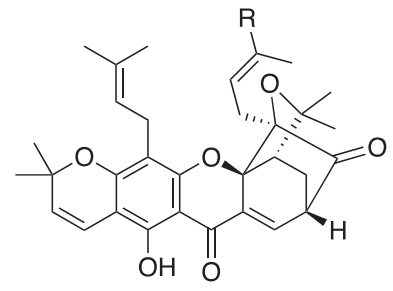

isomorellin $\quad(101) \mathrm{R}=\mathrm{CHO}$ isomorellinol (102) $\mathrm{R}=\mathrm{CH}_{2} \mathrm{OH}$

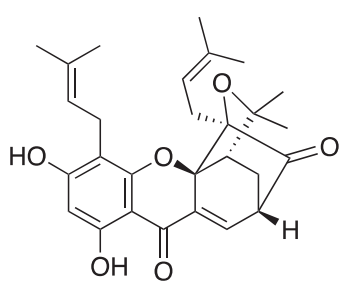

forbesione (103)

Figure 8 Structures of several bioactive caged xanthones.

antiproliferative activity $\left(\mathrm{IC}_{50}<7 \mu \mathrm{M}\right)$ in human umbilical vein endothelial cells (HUVECs) [23]. Among them, remarkable antiangiogenic activity has been found for isogambogic acid, gambogenin and morellic acid tested in an in vivo zebrafish model. These compounds have lower toxicity than gambogic acid, according to death and heart rates. Thus, gambogenin has been strongly suggested to be a potential angiogenesis inhibitor, given its potent activity and absence of toxicity at 8-16 $\mu \mathrm{M}$.

In addition, six compounds $(32,82,83$, bractatin, isobractatin and 1-O-methylisobractatin) are active ( $\mathrm{IC}_{50} \leq$ $5.10 \mu \mathrm{M})$ against A549, human leukemia HL-60, human hepatocarcinoma SMMC-7721, human breast adenocarcinoma MCF-7 and human colon cancer SW480 cell lines [31]. Natural products 37, 70, gambogoic acid B, 30-hydroxygambogic acid, 30-hydroxyepigambogic acid, formoxanthone J, epiformoxanthone J, isomorellic acid, isogambogenic acid, gambogenin and gambogellic acid have also been found to be cytotoxic, with $\mathrm{IC}_{50}<8 \mu \mathrm{M}$ against A549, HCT116 and triple-negative breast cancer MDA-MB-231 cell lines [25]. Caged xanthones 21, 38 and 44 have been shown to decrease the viability of A549 cells by inducing apoptosis [22]. Compound 24 has an $\mathrm{IC}_{50}=2.05$ and $2.20 \mu \mathrm{M}$ against HCT116 and MDA-MB-231 cell lines, respectively; whereas 36 has activity at $2.09 \mu \mathrm{M}$ against the triple-negative breast cancer MDA-MB-231 cell line [25]. Meanwhile, (+)-/(-)-82, (+)-/(-)-83 and (-)-bractatin have potent activity $\left(\mathrm{IC}_{50}=1.47-7.02 \mu \mathrm{M}\right)$ against HCT116 cells [30], whereas 30 and (-)-59 have only weak activity $\left(\mathrm{IC}_{50}=23.95\right.$ and $14.23 \mu \mathrm{M}$, respectively), as compared with that of the positive control doxorubicin, with $\mathrm{IC}_{50}$ value of $9.74 \mu \mathrm{M}$ [27].

All eight compounds (48, 58, 71, deoxygaudichaudione A, gambogenic acid, desoxygambogenin, hanburin and desoxymorellin) exhibit good activity against A549,
HCT116, HepG2 and human breast cancer SK-BR-3 cell lines, with an $\mathrm{IC}_{50}<10 \mu \mathrm{M}$ [33]. Compound 12, gaudichaudione $\mathrm{H}$ and cantleyanone $A$ display $\mathrm{IC}_{50}$ values of less than $9 \mu \mathrm{M}$ in A549, HepG2, PC-3, human colorectal adenocarcinoma HT-29 and human colorectal adenocarcinoma HL-7702 cell lines [19]. Compounds 28, 29, gambogellic acid and its epimer have been reported to show excellent cytotoxicity against A549 and human hepatocarcinoma SMMC-7221 cells, with $\mathrm{IC}_{50}$ values ranging from 1.07 to $2.10 \mu \mathrm{M}$, as compared with that of the positive control cisplatin, with $\mathrm{IC}_{50}$ values of 9.38 and $11.4 \mu \mathrm{M}$, respectively [26].

Cytotoxic studies in HeLa human cervical cell lines have revealed several bioactive compounds with $\mathrm{IC}_{50}<9 \mu \mathrm{M}$, including 2-5, 22-23, 25-27, 31, 36, 46-47, 49-50, 70, 81-82, isobractatin, gaudichaudione $\mathrm{H}$ and gambogenic acid [15, 24, 32, 68, 69]. Caspase 3 activation, as evidenced by poly(ADP-ribose) polymerase (PARP) cleavage, has been observed in HeLa cells treated with $\mathbf{8 2}$ [69], gaudichaudione $H$ [68], and isobractatin [69], thus suggesting that apoptosis induction is involved in their antiproliferative effect. Gaudichaudione $\mathrm{H}$ and isobractatin have also been reported to increase the sub-G1 fraction in A549 lung carcinoma cells [69]. Furthermore, 82 and isobractatin have been shown to suppress autophagic flux in both cell lines [69]. These compounds convert light chain 3B-I (LC3B-I) to LC3B-II, increase production of p62 proteins at high concentration $(4 \mu \mathrm{M})$ and induce puncta formation.

Moreover, 13-15, 32, 66', 77-78, 82-84, 87-88, bractatin, isobractatin, neoisobractatins $A$ and $B$, as well as 1-O-methyl-77, have been shown to possess growth-inhibitory activities against HL-60 (promyelocytic leukemia) and K562 (chronic myeloid leukemia) cell lines, with $\mathrm{GI}_{50}$ values between 0.2 and $8.8 \mu \mathrm{M}[20,63]$. When 
tested against $\mathrm{K} 562$ cells, potent activity has also been observed for 43, with an $\mathrm{IC}_{50}=2.5 \mu \mathrm{M}$ [18]. Compound 1 inhibits the growth of murine leukemia P388 and P388/ADR cells, with $I_{50}$ values of 0.243 and $7.60 \mu \mathrm{M}$, respectively [14]. Compounds 8, 9, gaudichaudic acid E and isogaudichaudic acid E show strong inhibitory activity, with $\mathrm{IC}_{50}$ values from 4.7 to $9.7 \mu \mathrm{M}$ against MCF-7, human melanoma A-375 and human breast carcinoma SKBR-3 cells [17]. Moreover, investigations of $\mathbf{3 0}$ and $\mathbf{8 2}$ have shown marked inhibitory activity against HepG2, MCF-7 and T98 (human glioblastoma multiforme) cell lines, with $\mathrm{IC}_{50}$ between 3.21 and $6.27 \mu \mathrm{M}$ [28]. Cochinchinone $C$ and a mixture of 95/96 have excellent activity against the MCF-7 cell line [39]. The compounds $(-)-6,(-)-7,(-)-34,(-)-56,93$ and (-)-morellic acid exhibit significant cytotoxicity toward the HT-29 colon cancer cell line, with an $\mathrm{ED}_{50}$ less than $6 \mu \mathrm{M}[16,38]$. Compound 93 also displays good activity $\left(\mathrm{IC}_{50}=3.3 \mu \mathrm{M}\right)$ in mitochondrial transmembrane potential assays [38].

In 2015, 64 Garcinia compounds including 13 caged xanthones were screened against a wide spectrum of cancer cell lines [70]. Although all compounds demonstrated excellent activity toward all cell lines (except $\mathrm{H} 1573$ cells), with $\mathrm{IC}_{50}$ values less than $5 \mu \mathrm{M}$, the lowest $\mathrm{IC}_{50}$ was observed toward the $\mathrm{NCl}-\mathrm{H} 1650$ cell line. Further study revealed that 33-hydroxyepigambogic acid and 35-hydroxyepigambogic acid were the most potent inhibitors of $\mathrm{NCl}-\mathrm{H} 1650$ cell growth and colony formation [70]. Both compounds dose-dependently increased the activity of caspase 3 and 7 in NCl-H1650 cells, and cell cycle analysis showed significant accumulation of $S$ or G2/M phase cells. Several proapoptotic BH3-only genes, such as PUMA, Noxa and cell death involved p53-target (CDIP), were upregulated. Inhibition of Janus kinase (JAK) activity, particularly that of JAK2, was observed, thus affecting the expression and phosphorylation of signal transducer and activator of transcription 3 (STAT3), as shown by western blot analysis. Phosphorylation of extracellular signal-regulated kinase (ERK) and protein kinase B (Akt) was also inhibited. The findings suggest that both compounds exert cytotoxicity by targeting the JAK-STAT signaling pathway.

\subsubsection{Gambogic acid and derivatives}

Gambogic acid (97, Figure 8), extracted from the resin of $G$. hanburyi, demonstrates significant cytotoxicity against several cancer types including but not limited to breast, lung, liver, colorectal and prostate cancers, and melanoma [71-76]. This compound exerts antiproliferative, antimetastatic and antiangiogenic properties through apoptosis induction [77, 78], reactive oxygen species (ROS)-induced endoplasmic reticulum (ER) stress $[72,79]$, autophagy $[80,81]$ and modulation of various cellular pathways, such as nuclear factor $\kappa$-light-chainenhancer of activated B cells (NF-kB) [82, 83], Akt/mammalian target of rapamycin (mTOR) [80, 84], phosphoinositide 3-kinase (PI3K)/Akt [75, 76], c-Jun N-terminal kinase (JNK) $[79,85]$ and mitogen-activated protein kinase (MAPK) $[86,87]$ pathways. Moreover, it enhances chemosensitivity or synergistically potentiates the anticancer effects of various chemotherapeutic agents, such as docetaxel $[88,89]$, doxorubicin $[85,90]$, chloroquine [91], cisplatin [86], vorinostat [92], 5-fluorouracil [93] and others [94, 95].

Despite having promising anticancer properties and high selectivity for cancer cells over normal cells [96], the low aqueous solubility of gambogic acid hinders its potential clinical applications. Continual efforts to elucidate the minimum pharmacophore of gambogic acid for subsequent enhancement of drug-like properties has revealed promising candidates worthy of further study. In 2007, the Theodorakis group discovered that cluvenone (98, Figure 8), a synthetic gambogic acid derivative, is a potential inhibitor of angiogenesis [97]. It exerts cytotoxicity against HUVECs, with $\mathrm{IC}_{50}=1.38 \mu \mathrm{M}$, through apoptosis induction [97]. The antiproliferative properties of cluvenone against cancer and multidrug resistant cells have been supported by evidence from a $\mathrm{NCl}-60$ human tumor cell line screen indicating $\mathrm{GI}_{50}$ values between 0.1 and $2.7 \mu \mathrm{M}$ [98]. This compound also induces apoptosis in human T-cell acute lymphoblastic leukemia (ALL) CEM cells $\left(E_{50}=0.25 \mu \mathrm{M}\right)$ and has demonstrated selective toxicity against primary B-ALL cells $\left(I C_{50}=1.1 \mu \mathrm{M}\right)$ compared with peripheral blood mononuclear cells from normal donors $\left(\mathrm{IC}_{50}=5.2 \mu \mathrm{M}\right)$ [98]. The antiproliferative effect of cluvenone bypasses the mechanisms of multidrug resistance conferred by P-glycoprotein, and its inhibitory activity against HL-60 and HL-60/ADR cell lines does not significantly differ [97-99]. Gene expression profiling has suggested that cluvenone activates the MAPK pathway along with its downstream nuclear factor-erythroid factor 2-related factor 2 (Nrf2)-mediated oxidative stress response signaling pathway, on the basis of observations of upregulation of heat shock protein family $A$ member $1 \mathrm{~A}$ (HSPA1A), HSPA8, p38 and other stress-associated genes [98]. Cluvenone has also been demonstrated to induce apoptosis by dissipating the mitochondrial membrane potential in HeLa cells and promoting the release of cytochrome $\mathrm{C}$ from mitochondria to the cytoplasm in CEM cells [100]. The resultant activity of caspase 9 and caspase 3 is therefore enhanced $[100,101]$. At low micromolar concentrations, this compound induces degradation of Hsp90 client proteins and PARP cleavage [101]. In addition, cluvenone induces formation of ROS in the PC3 human prostate cancer cell line, thus inducing cell stress and apoptosis [98].

DD06101 (102), also known as MAD28, is another gambogic acid derivative that has attracted widespread attention because its activity is comparable to that of gambogic acid. The antiproliferative activity of DD06101 against HepG2 cell lines is highly similar to that of gambogic acid $\left(\mathrm{IC}_{50}=2.37\right.$ and $2.40 \mu \mathrm{M}$, respectively) [102]. Mechanistic studies have revealed that DD06101 induces G2/M phase cell cycle arrest and promotes apoptosis by decreasing the expression 
of $\mathrm{Bcl}-2$ and procaspase 3 while increasing the activity of caspase 3. Screening of (+)-, (-)- and ( \pm )-DD06101 against a panel of breast cancer cell lines (SKBR3, BT474, MDA-MB-231, MCF-7, MDA-MB-468 and MARY-X) has demonstrated potent activity with $\mathrm{IC}_{50}$ ranging from 0.6 to $3.8 \mu \mathrm{M}$, with a dose-dependent increase in cleavedPARP, caspase 3 and caspase 7 [103]. Studies of other bioactive cluvenone derivatives are underway [104-109].

\subsubsection{Gambogenic acid}

Gambogenic acid (100, Figure 8) was first discovered and isolated from G. hanburyi in 1996 [62]. Extensive research has focused on the mechanistic study of this natural compound, because it demonstrates potent anticancer properties by modulating various cellular signaling pathways in cancer cells (Figure 9). In vitro studies against many cell lines, including lung cancer, nasopharyngeal cancer, colon cancer, glioblastoma, breast cancer, gastric cancer and melanoma, have shown that gambogenic acid inhibits cancer cell proliferation mainly through mitochondria-mediated apoptosis induction and cell cycle arrest at G0/G1 phase [110-118]. The apoptotic effect of gambogenic acid is also associated with decreased protein levels of p38, MAPK and p-ERK $1 / 2$ $[119,120]$, and the inactivation of Akt signaling pathway $[113,115,117]$.

In the B16 mouse melanoma cell line, gambogenic acid not only induces apoptosis by inhibiting the expression of p-PI3K, p-Akt and p-mTOR [121], but also promotes autophagy via upregulation of the ROS/ sirtuin 3 (SIRT3)/adenosine monophosphate-activated protein kinase (AMPK) pathway [122]. It also suppresses metastasis of melanoma cells by targeting proteins associated with epithelial-mesenchymal transition [118] and promoting ferroptosis through activation of p53/solute carrier family 7 member 11 (SLC7A11)/glutathione peroxidase 4 (GPX4) [123]. Moreover, gambogenic acid degrades cancerous inhibitor of protein phosphatase 2A (CIP2A) in hepatocellular carcinoma via the ubiquitin-proteasome pathway [124]. Downregulation of its associated downstream molecules, that is, c-Myc and p-Akt, has been observed. Furthermore, gambogenic acid exerts anti-inflammatory and antiapoptotic effects against in vivo acute hepatotoxicity by regulating the $\mathrm{PI} K \mathrm{~K} / \mathrm{Akt}$ and NF-KB signaling pathways [125]. Its inhibitory effect on NF- $\mathrm{KB}$ signaling has also been found to suppress growth and metastasis of bladder cancer cells [126]. In HepG2/Adr cells, gambogenic acid downregulates P-glycoprotein expression, possibly via inhibition of NF-KB and MAPK pathways [127].

In addition, gambogenic acid has been found to promote autophagy of lung cancer cells through glycogen synthase kinase 3 beta (GSK3 $\beta$ ) activation and suppression of Akt/mTOR [128]. Gambogenic acid suppresses the acidification of lysosomes, and hinders the fusion of autophagosomes and lysosomes, and consequently lysosomal degradation and autophagy induction [129]. This compound exerts antiproliferative effects against erlotinib-resistant non-small-cell lung cancer cell lines and patient-derived xenografts by downregulating the fibroblast growth factor receptor (FGFR) signaling pathway [130]. Synergistic growth inhibition of lung cancer cells has also been observed after combined treatment with gambogenic acid and

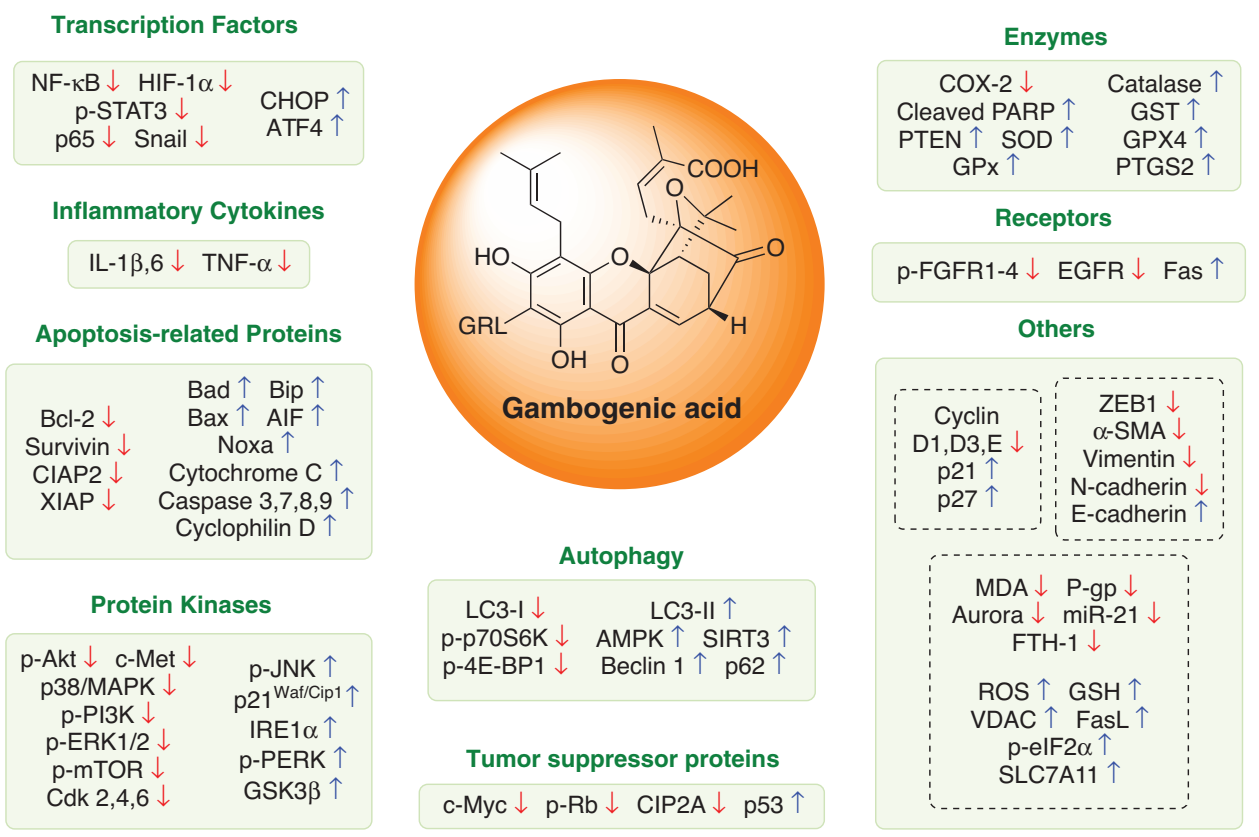

Figure 9 | Molecular targets of gambogenic acid. 
5-fluorouracil, in which the activation of cancer cell death is caused by both caspase-independent necroptosis and caspase-dependent apoptosis [131].

The $\mathrm{Li}$ research group has shown that gambogenic acid triggers ER stress by activating volume-sensitive outwardly rectifying chloride channels, thus leading to apoptosis of human nasopharyngeal carcinoma CNE-2Z cells [132]. The ER stress induced by gambogenic acid and caused by increased ROS production also activates inositol-requiring enzyme-1 $\alpha$ (IRE $1 \alpha)$, apoptosis signal regulating kinase 1 (ASK1) and downstream JNK, thus causing Noxa-mediated apoptosis [133]. In colorectal cancer, gambogenic acid shows good antiproliferative activity by inducing ER stress via downregulation of the Aurora A pathway, which plays a crucial role in cell division [134].

Furthermore, gambogenic acid has excellent antitumor activity against hypoxic multiple myeloma cells by decreasing hypoxia-inducible factor 1-alpha (HIF-1 $\alpha$ ) accumulation and STAT3 phosphorylation, which play important roles in the modulation of miR-21/phosphatase and tensin homolog (PTEN) expression [135] Combination treatment with gambogenic acid/bortezomib has significant synergistic effects on apoptosis induction in MM.1S multiple myeloma cells through G2/M cell cycle arrest and modulation of p53/ROS/p38 MAPK signal transduction [136]. Moreover, gambogenic acid potentiates adriamycin-induced apoptosis in MCF-7/ADR cells via G0/G1 arrest and downregulation of the PTEN/PI3K/Akt pathway [137].
Unfortunately, gambogenic acid induces a thiol-dependent heat shock response by disrupting the interaction between heat shock protein 90 (HSP90) and heat shock factors (HSF) 1 or 2 [138], which are associated with cytoprotection of cancer cells [139], thus suggesting a need for further investigations.

\subsubsection{Isomorellin and forbesione}

The biological activities and mechanisms of action of isomorellin (101) and forbesione (103) against cholangiocarcinoma has been a major research area for Reutrakul's research team since 2010 (Figure 8) [140144]. Four caged xanthones, gambogic acid, 101, isomorellinol (102) and 103, have been tested against two cholangiocarcinoma cell lines, KKU-100 and KKU-M156 [140]. All compounds displayed potent cytotoxicity, with $\mathrm{IC}_{50}$ from 0.02 to $2.64 \mu \mathrm{M}$. The compounds induced apoptosis in both cell lines partly by downregulating $\mathrm{Bcl}-2$ and survivin proteins while upregulating Bax protein and apoptosis-inducing factor (AIF) (Figure 10). Consequently, activation of caspase 3 and 9 , and an increase in the $\mathrm{Bax} / \mathrm{Bcl} 2$ ratio were observed, thus suggesting that the anticancer properties of these four compounds are mediated by mitochondrial-dependent apoptosis.

Further mechanistic study has shown that isomorellin induces cell cycle arrest at G0/G1 phase via regulation of the $\mathrm{p} 53$ and NF- $\mathrm{KB}$ signaling pathways, thereby promoting apoptosis in both cells [141]. This compound increases the expression of p53 tumor suppressor

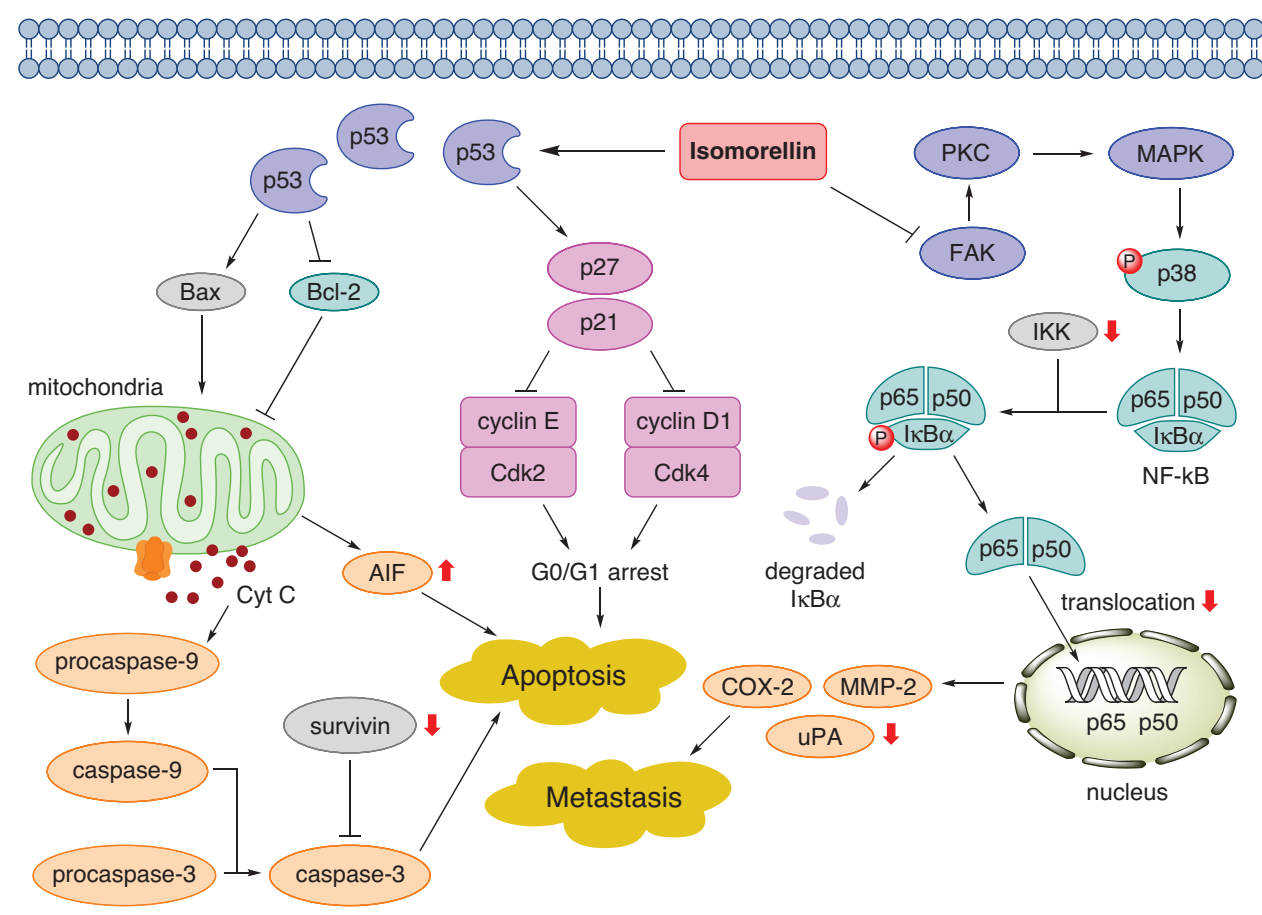

Figure 10 | Proposed anticancer mechanisms of isomorellin. 
protein and cyclin-dependent kinase inhibitors p21 and p27, while decreasing the expression of cyclin D1, cyclin E, and the cyclin-dependent kinases Cdk2 and Cdk4. Moreover, isomorellin decreases cell viability, migration and invasion of KKU-100 cells [142] This compound also blocks the activity of focal adhesion kinase (FAK), protein kinase C (PKC) and the downstream p38-MAPK pathway, thereby upregulating the expression of $I \kappa B \alpha$, an inhibitor of NF- $\mathrm{KB}$. Consequently, the translocation of NF-KB/p65 into the nucleus is inhibited, thus suppressing the expression of matrix metalloproteinase-2 (MMP2), urokinase-type plasminogen activator (UPA) and cyclooxygenase-2, (COX-2) which are associated with invasion and metastasis of cancer cells.

Synergistic effects of isomorellin and forbesione with doxorubicin on growth inhibition and apoptosis induction have been assessed in KKU-100, KKU-M139, KKUM156 human cholangiocarcinoma and Chang liver cell lines [143]. Either of the caged xanthones alone selectively inhibited the growth of cholangiocarcinoma cells but not Chang cells. A combination of isomorellin and doxorubicin exhibited enhanced bioactivity on KKUM139 and KKU-M156 cells, whereas the forbesione/ doxorubicin pair displayed synergistic inhibitory activity on KKU-100 and KKU-M139 cells. An in-depth study has revealed that the combined treatments induce apoptosis by stimulating the expression of $\mathrm{Bax} / \mathrm{BCl}-2$ ratio, caspase 9 and caspase 3 , while downregulating the expression of survivin, procaspase 9 and procaspase 3. Inactivation of the NF- $\mathrm{KB}$ pathway-as evidenced by decreased NF- $\mathrm{KB} /$ p65 expression and phosphorylated IKB $\alpha$ levels, along with suppression of multidrug resistance-associated protein 1 (MRP1) protein expression-also plays a pivotal role in their synergistic growth-inhibitory effects.

Forbesione has been demonstrated to inhibit the growth of the Ham-1 hamster cholangiocarcinoma cell line and Ham-1 allografts in a hamster model, with no observed in vivo toxicity or adverse effects [144]. This compound arrests the cell cycle at $S$ phase through decreasing the protein expression of cyclin $A$, cyclin $E$ and $\mathrm{Cdk2}$, as well as promoting the upregulation of p21 and p27. Multiple key signaling pathways participate in forbesione-mediated apoptosis. Increased expression of Fas, Fas-associated death domain (FADD) and caspase 3, accompanied by decreased procaspase 8 and procaspase 3 levels, has indicated the involvement of the death receptor pathway. The mitochondrial pathway is also triggered by induction of $B a x, 1 \kappa B \alpha$ and caspase 9, with suppression of the protein levels of $\mathrm{BCl}-2$, procaspase 9 and $\mathrm{NF}-\mathrm{KB} / \mathrm{p} 65$. A plausible ER pathway has been proposed in view of the increased expression of caspase 12 along with decreased expression of procaspase 12.

\subsubsection{Neobractatin}

As demonstrated in Section 3.1.1, neobractatin (82) exhibits significant cytotoxicity against various cancer cell lines. Testing of this natural compound against seven cancer cell lines (HeLa, A549, MCF-7, SH-SY5Y, PC-3, $\mathrm{K} 562$ and U937) by our group has indicated potent cytotoxicity, with $\mathrm{IC}_{50}$ values $<4 \mu \mathrm{M}$ within $24 \mathrm{~h}$; moreover, an in vivo study on HeLa mouse xenograft models has exhibited decreased tumor growth and weight, with no observed toxicity [145]. A detailed mechanistic study has revealed that neobractatin induces $\mathrm{G} 1 / \mathrm{S}$ phase arrest by decreasing E2F/DP heterodimeric transcription factor 1 (E2F1) activity (Figure 11). Simultaneously, neobractatin upregulates growth arrest and DNA damage-inducible protein 45 alpha (GADD45 $\alpha$ ), decreases the expression of cyclin B1 and disrupts the mitotic spindle, thus arresting synchronized HeLa cells in G2/M phase.

Moreover, neobractatin has been demonstrated to be active against breast and lung cancer cell metastasis [146]. This compound inhibits metastasis both in vitro and in vivo, partly via upregulation of muscleblind-like protein 2 (MBNL2), which has diminished expression in breast or lung cancer tumor tissue. An increase in MBNL2

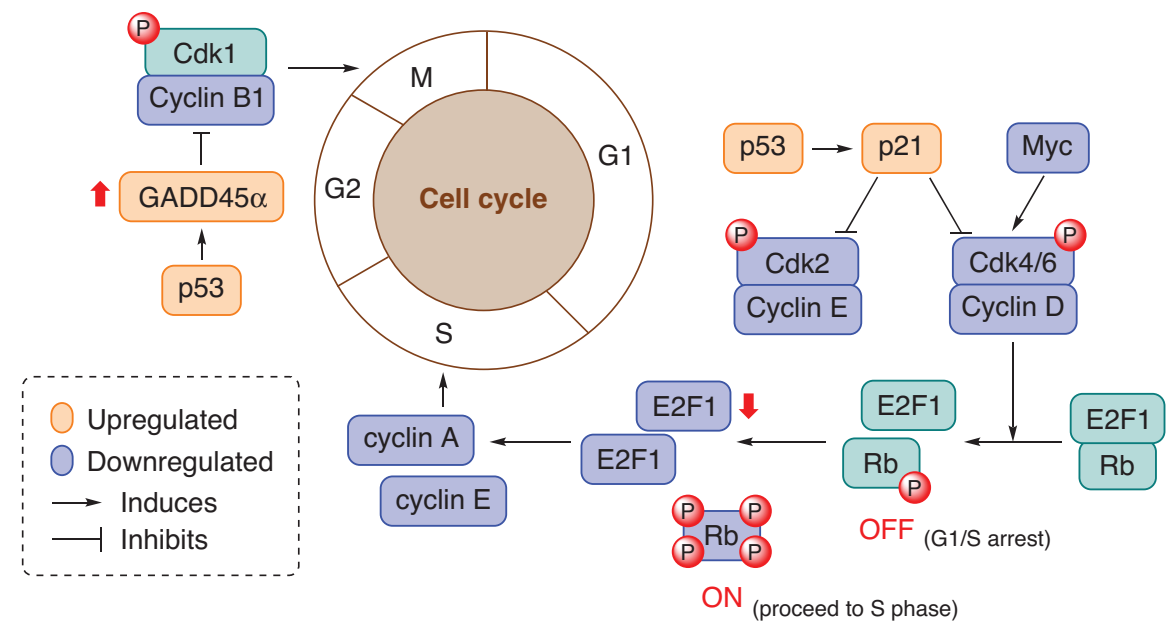

Figure 11 | Neobractatin-induced G1/S and G2/M cell cycle arrest. 
in turn alters the modulation of p-Akt/epithelial-mesenchymal transition signaling pathway and the expression of related proteins such as vimentin, cofilin and MMP- 2 .

The composition of bractatin and neobractatin has been found to have inhibitory activity against throat cancer cells (Hep-2 and FaDu) and Hep-2 xenograft models [147]. These compounds promote apoptosis by regulating multiple signaling pathways involved in ER stress-induced apoptosis, mitochondria-mediated apoptosis and inhibition of the Akt/GSK-3 $\beta /$ Bad pathway.

\subsection{Anti-inflammatory activities}

The compounds 8-methoxy-8,8a-dihydrobractatin (77), bractatin, isobractatin and neobractatin (82) inhibit nitric oxide production with a lower $\mathrm{IC}_{50}(1.22-8.96 \mu \mathrm{M})$ than that of the positive control dexamethasone [28] Furthermore, gambogenic acid and gaudichaudione $\mathrm{H}$ display good anti-inflammatory effects in macrophages via inhibition of the NF- $\kappa B$ and MAPK signaling pathways $[148,149]$. The latter compound has also been tested in colitis mouse models induced by dextran sodium sulfate and found to inhibit the phosphorylation of AMPK $\alpha$ and proline-rich Akt substrate of $40 \mathrm{kDa}$ (PRAS40) [149]. Pro-inflammatory mediators and cytokines such as interleukin-6, COX-2, tumor necrosis factor- $\alpha$ (TNF- $\alpha$ ) and inducible nitric oxide synthase (iNOS) are downregulated in LPS-stimulated RAW 264.7 cells and colon tissues in mouse models. In addition, gambogenic acid has been shown to decrease hypertrophic scar formation by controlling the local inflammatory response, neoangiogenesis and growth factor expression during the wound healing process [150].

\subsection{Miscellaneous activities}

Only a small number of caged xanthones have been tested for potential bioactivity beyond anticancer effects. Moreollic acid, 10-methoxygambogenic acid, gambogoic acid, morellic acid, gambogenic acid and 93 have been found to competitively inhibit $\left(\mathrm{IC}_{50}=0.47-\right.$ $6.6 \mu \mathrm{M}$ ) protein tyrosine phosphatase 1B (PTP1B) [37,
151], an important modulator of insulin signaling, and a potential target for the treatment of cancer and obesity [152-154], These compounds, along with 51-54, 71, $10 \alpha$-hydroxygambogic acid, desoxymorellin, gambogin, gambogellic acid and desoxygambogenin, also exhibit inhibitory activity against $\alpha$-glucosidase [34, 155].

Morellic acid has antibacterial effects against methicillin-resistant Staphylococcus aureus USA300, with an MIC value of $12.5 \mu \mathrm{M}$, but its toxicity hinders its future applications and may warrant structural modification [156]. Two synthetic cluvenone derivatives (CR135 and CR142), which exist as triphenylphosphonium salts, exhibit antimalarial activity against Plasmodium falciparum [157].

\section{STRUCTURE-ACTIVITY RELATIONSHIPS}

The intact caged D ring plays an essential role in maintaining the cytotoxicity of caged xanthones against cancer cell lines (Figure 12) [97]. This scaffold has antiproliferative effects on cancer cells and inhibits $I \kappa B$ kinases (IKKs), the key regulators of NF- $\mathrm{KB}$ activation [158]. Replacing the oxa-caged $D$ ring with an aza-caged ring is also feasible with inclusion of a hydrophobic moiety on the nitrogen atom; this modified compound shows significant increase in cytotoxicity and IKK $\beta$ inhibitory activity [105]. The unsaturated double bond at C-8/8a appears to significantly contribute to apoptosis induction and antitumor activity [99, 109, 159, 160]. Additionally, the Theodorakis and You research groups have independently reported that the gem-dimethyl groups at C-28 and C-33 are crucial for these compounds' cytotoxicity [97, 161]. However, the presence of a C-33 gem-dimethyl has been found to be inessential for cytotoxicity against HepG2 cells; substitution of this moiety by hydrogen atoms is tolerated but oxidation of C-33 to carbonyl have been found to decrease the activity [104]. In a later study, You has proposed that the C-28 geminal dimethyl group contributes to Hsp90 activity, but the C-33 geminal-dimethyl decreases its activity [109].

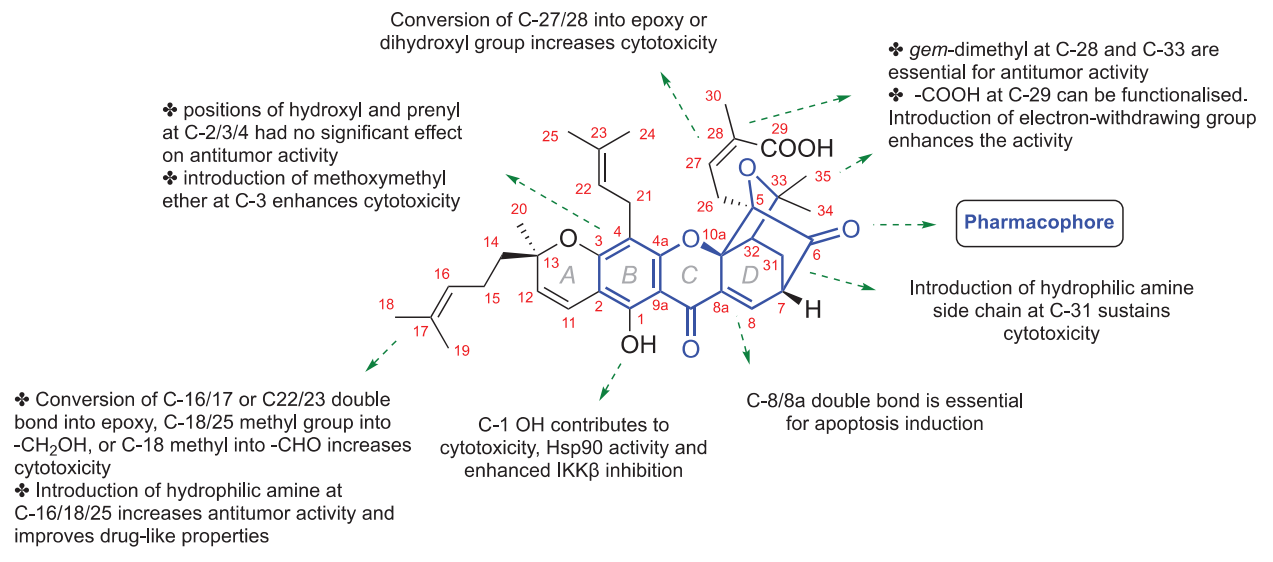

Figure 12 | General SARs of caged xanthones on antitumor activity 
Modifications of the C-27/28 double bond to a dihydroxyl or epoxy group enhance cytotoxicity against the A549, MCF-7 and BGC-823 cell lines, among which the epoxy group confers better inhibition than the dihydroxyl group, except against A549 cells [162]. Functionalization of the carboxylic acid moiety at C-29 appears to be tolerated, thus indicating that this group could be modulated to improve physiochemical properties [99, 109, 159]. Introduction of an electron withdrawing group at C-29 improves the inhibitory activity against A549 cells [162]. Moreover, introduction of a hydrophilic amine side chain at C-31 maintains cytotoxicity while increasing water solubility and cell permeability, whereas a hydrophobic amine moiety diminishes the bioactivity [104].

In contrast, the aromaticity of the A ring must be maintained, because oxidation of the $A$ ring to quinone leads to a complete loss of activity [163]. The presence of a hydroxyl group at the C-1 position is an important structural feature for antitumor activity [102, 161, 163] and has been found to enhance IKK $\beta$ inhibitory activity [158]. Activity is preserved when the hydroxyl group is methylated or acylated [159], but replacing the hydroxyl group with a prenyl group is unfavorable [161]. The positions of hydroxyl, prenyl or fused pyran moieties on C-2, C-3 and C-4 have no significant correlation with antitumor activity [104, 158, 161]. Meanwhile, a free hydroxyl group at C-3 decreases the cytotoxicity [163], but converting it to methoxymethyl ether enhances the activity [162].

Furthermore, modification of the double bond at $\mathrm{C}-16 / 17$ or C-22/23 to an epoxy group, and conversion of the methyl group at $\mathrm{C}-18$ or $\mathrm{C}-25$ into $-\mathrm{CH}_{2} \mathrm{OH}$ or $\mathrm{C}-18$ methyl into - $\mathrm{CHO}$ provides better inhibitory activity against cancer cells $[164,165]$. Introduction of hydrophilic amines at C-16, C- 18 or C-25 increases the antitumor activity and improves drug-like properties [166-168].

Regarding antibacterial properties, Jiarpinitnun et al. have reported that the C-29 carboxylic acid moiety is crucial for growth inhibition against methicillin-resistant Staphylococcus aureus USA300. Switching this functionality to less polar substituents diminishes the antibacterial activity and may increase the cytotoxicity [156]. In contrast, the prenyl side chain at C-13 is not necessary for bioactivity.

\section{CONCLUSIONS AND FUTURE PERSPECTIVES}

Since the isolation of morellin in 1937, a total of 194 caged xanthones have been identified mostly from Garcinia species, and several have been identified from Cratoxylum plants. Modifications on the $B$ and $D$ rings of the caged xanthone scaffold by additional cyclization and/or side chain substitutions expand the structural diversity of this family of compounds. In general, caged xanthones can be characterized on the basis of the presence or absence of $\Delta^{8 / 8 a}$ and the $A$ ring. The study and analysis of caged xanthones according to this classification is highly important, because available structure-activity relationship (SAR) studies have suggested that the double bond between $C-8$ and $C-8 a$ is essential for cytotoxicity, and the absence of an A ring does not affect biological activity [102, 159, 160]. On this basis, systematic SAR evaluations of other substitutions are warranted.

The unique architecture of caged xanthones results in potent bioactivities, particularly anticancer properties. Among them, gambogic acid has received the most attention, and its mechanism of action has been widely studied. The other natural compounds, although subjected to cancer cell line screening, have not been more deeply investigated. Only isomorellin and forbesione have been studied mechanistically against cholangiocarcinoma, and studies have also investigated gambogenic acid, neobractatin and gambogic acid derivative, i.e., cluvenone. In-depth research to discover optimal lead caged xanthones with excellent drug-like properties remains necessary. Discovery of other potential biological properties of caged xanthone beyond anticancer properties, and evaluation of toxicity should also be undertaken.

\section{ACKNOWLEDGEMENTS}

We are grateful to the National Natural Science Foundation of China (81973438, 82174025), the NSFC-Joint Foundation of Yunnan Province (U1902213), the Fok Ying-Tong Education Foundation (161039), and the Guangdong Province Key Area R\&D Program of China (2020B1111110003) for their financial support.

\section{REFERENCES}

[1] Cooper WE: A Taxonomic Revision of Garcinia L. (Clusiaceae) in Australia, Including Four New Species from Tropical Queensland. Austrobaileya 2013, 9(1):1-29.

[2] POWO Plants of the World Online [http://www. plantsoftheworldonline.org] Accessed on date $3 \mathrm{Dec}$ 2021.

[3] Pedraza-Chaverri J, Cárdenas-Rodríguez N, Orozco-Ibarra M, Pérez-Rojas JM: Medicinal Properties of Mangosteen (Garcinia mangostana). Food and Chemical Toxicology 2008, 46(10):3227-3239.

[4] Farnsworth NR, Bunapraphatsara N: Thai Medicinal Plants Recommended for Primary Health Care System. Medicinal Plant Information Center; 1992.

[5] Espirito Santo BLSd, Santana LF, Kato Junior WH, de Araújo FdO, Bogo D, Freitas KdC et al.: Medicinal Potential of Garcinia Species and their Compounds. Molecules 2020, 25(19):4513.

[6] Liu Y, Chen Y, Lin L, Li H: Gambogic Acid as a Candidate for Cancer Therapy: A Review. International Journal of Nanomedicine 2020, 15:10385-10399.

[7] Wan H-Y, Chen J-L, Yu X-Y, Zhu X-M: Titania-coated Gold Nanorods as an Effective Carrier for Gambogic Acid. RSC Advances 2017, 7(78):49518-49525.

[8] Sukpondma Y, Rukachaisirikul V, Phongpaichit S: Antibacterial Caged-tetraprenylated Xanthones from the Fruits of Garcinia hanburyi. Chemical \& Pharmaceutical Bulletin 2005, 53(7):850-852. 
[9] Rao GS, Mala SR, Surendranath V, Gupta V, Rao PN: The Structure of Moreollin. Tetrahedron Letters 1974, 15(14):1259-1262.

[10] Wu J, Xu Y-J, Cheng X-F, Harrison LJ, Sim K-Y, Goh SH: A Highly Rearranged Tetraprenylxanthonoid from Garcinia gaudichaudii (Guttiferae). Tetrahedron Letters 2001, 42(4):727-729.

[11] Rukachaisirikul $V$, Painuphong $P$, Sukpondma $Y$, Koysomboon S, Sawangchote P, Taylor WC: Cagedtriprenylated and -Tetraprenylated Xanthones from the Latex of Garcinia scortechinii. Journal of Natural Products 2003, 66(7):933-938.

[12] Thoison O, Fahy J, Dumontet V, Chiaroni A, Riche C, Tri MV et al.: Cytotoxic Prenylxanthones from Garcinia bracteata. Journal of Natural Products 2000, 63(4):441-446.

[13] Han QB, Xu HX: Caged Garcinia Xanthones: Development Since 1937. Current Medicinal Chemistry 2009, 16(28):3775-3796.

[14] Wang LL, Li ZL, Xu YP, Liu XQ, Pei YH, Jing YK, et al.: A New Cytotoxic Caged Polyprenylated Xanthone from the Resin of Garcinia hanburyi. Chinese Chemical Letters 2008, 19(10):1221-1223.

[15] Tao S-J, Guan S-H, Wang W, Lu Z-Q, Chen G-T, Sha N, et al.: Cytotoxic Polyprenylated Xanthones from the Resin of Garcinia hanburyi. Journal of Natural Products 2009, 72(1):117-124

[16] Ren Y, Lantvit DD, de Blanco EJC, Kardono LBS, Riswan S, Chai $\mathrm{H}$, et al.: Proteasome-inhibitory and Cytotoxic Constituents of Garcinia lateriflora: Absolute Configuration of Caged Xanthones. Tetrahedron 2010, 66(29):5311-5320.

[17] Menon LN, Satheesh SKK, Panicker SP, Rameshkumar KB: Antiproliferative Activity of Caged Xanthones from the Leaves of Garcinia wightii T. Anderson. Fitoterapia 2020, 143:104592.

[18] Yang J-L, Fu W-W, Xiang Q, Wu R, Tang Y-X, Zheng C-W, et al.: Cytotoxic 7-methoxylated Caged Xanthones from the Twigs of Garcinia oligantha. Chinese Journal of Chemistry 2021, 39(10):2898-2910.

[19] Tang YX, Fu WW, Wu R, Tan HS, Shen ZW, Xu HX: Bioassayguided Isolation of Prenylated Xanthone Derivatives from the Leaves of Garcinia oligantha. Journal of Natural Products 2016, 79(7):1752-1761.

[20] Niu SL, Li DH, Li XY, Wang YT, Li SG, Bai J, et al.: Bioassayand Chemistry-guided Isolation of Scalemic Caged Prenylxanthones from the Leaves of Garcinia bracteata. Journal of Natural Products 2018, 81(4):749-757.

[21] Zhang BJ, Fu WW, Wu R, Yang JL, Yao CY, Yan BX, et al.: Bioactive Scalemic Caged Xanthones from the Leaves of Garcinia bracteata. Bioorganic Chemistry 2019, 82:274-283.

[22] Liu Q, Zheng H, Wang X, Zhou L, Wang S, Shen T, et al.: Cytotoxic New Caged-polyprenylated Xanthonoids from Garcinia oligantha. Fitoterapia 2022, 156:105092.

[23] Yang J, He S, Li S, Zhang R, Peng A, Chen L: In Vitro and In vivo Antiangiogenic Activity of Caged Polyprenylated Xanthones Isolated from Garcinia hanburyi Hook. f. Molecules 2013, 18(12):15305-15313.

[24] Tao S-J, Guan S-H, Li X-N, Gun D-A: A Highly Rearranged Pentaprenylxanthonoid from the Resin of Garcinia hanburyi. Helvetica Chimica Acta 2010, 93(7):1395-1400.

[25] Deng Y-X, Guo T, Shao Z-Y, Xie H, Pan S-L: Three New Xanthones from the Resin of Garcinia hanburyi. Planta Medica 2013, 79(9):792-796.
[26] Dong B, Zheng Y-F, Wen H-M, Wang X-Z, Xiong H-W, Wu $H$, et al.: Two New Xanthone Epimers from the Processed Gamboge. Natural Product Research 2017, 31(7):817-821.

[27] Sriyatep T, Andersen RJ, Patrick BO, Pyne SG, Muanprasat C, Seemakhan S, et al.: Scalemic Caged Xanthones Isolated from the Stem Bark Extract of Garcinia propinqua. Journal of Natural Products 2017, 80(5):1658-1667.

[28] Xue Q, Chen Y, Yin H, Teng H, Qin R, Liu H, et al.: Prenylated Xanthones and Benzophenones from the Fruits of Garcinia bracteata and Their Potential Antiproliferative and Anti-inflammatory Activities. Bioorganic Chemistry 2020, 104:104339.

[29] Na Z, Hu H-B, Fan Q-F: Three New Caged Prenylxanthones from Garcinia bracteata. Helvetica Chimica Acta 2010, 93(5):958-963.

[30] Sriyatep T, Tantapakul C, Andersen RJ, Patrick BO, Pyne SG, Muanprasat C, et al.: Resolution and Identification of Scalemic Caged Xanthones from the Leaf Extract of Garcinia propinqua Having Potent Cytotoxicities Against Colon Cancer Cells. Fitoterapia 2018, 124:34-41.

[31] Na Z, Hu H-B, Xu Y-K: Cytotoxic Caged Xanthones from the Fruits of Garcinia bracteata. Chemistry of Natural Compounds 2013, 49(3):505-506.

[32] Tao SJ, Wang $Y$, Zhang $X$, Guan SH, Guo DA: Biotransformation of Gambogenic Acid by Chaetomium globosum CICC 2445. Natural Product Communications 2012, 7(2):197-198.

[33] Deng Y-X, Pan S-L, Zhao S-Y, Wu M-Q, Sun Z-Q, Chen X-H, et al.: Cytotoxic Alkoxylated Xanthones from the Resin of Garcinia hanburyi. Fitoterapia 2012, 83(8):1548-1552.

[34] Chen Y, He S, Tang C, Li J, Yang G: Caged Polyprenylated Xanthones from the Resin of Garcinia hanburyi. Fitoterapia 2016, 109:106-112.

[35] Na Z, Hu HB, Fan QF: A Novel Caged-prenylxanthone from Garcinia bracteata. Chinese Chemical Letters 2010, 21(4):443-445.

[36] Niu S-L, Li D-H, Wang Y-T, Wang K-B, Lin B, Jing Y-K, et al.: Neobraclactones A-C, Three Unprecedented Chaise Longue-shaped Xanthones from Garcinia bracteata. Organic \& Biomolecular Chemistry 2017, 15(22):4901-4906.

[37] Li ZP, Lee $\mathrm{H}-\mathrm{H}$, Uddin Z, Song $\mathrm{YH}$, Park KH: Caged Xanthones Displaying Protein Tyrosine Phosphatase 1B (PTP1B) Inhibition from Cratoxylum cochinchinense. Bioorganic Chemistry 2018, 78:39-45.

[38] Ren Y, Matthew S, Lantvit DD, Tran Ngoc N, Chai H, Fuchs $\mathrm{JR}$, et al.: Cytotoxic and NF-KB Inhibitory Constituents of the Stems of Cratoxylum cochinchinense and Their Semisynthetic Analogues. Journal of Natural Products 2011, 74(5):1117-1125.

[39] Boonnak N, Chantrapromma S, Fun HK, Yuenyongsawad S, Patrick BO, Maneerat W, et al.: Three Types of Cytotoxic Natural Caged-scaffolds: Pure Enantiomers or Partial Racemates. Journal of Natural Products 2014, 77(7):1562-1571.

[40] Kartha G, Ramachandran GN, Bhat HB, Madhavan Nair P, Raghavan VKV, Venkataraman K: The Constitution of Morellin. Tetrahedron Letters 1963, 4(7):459-472.

[41] Yi T, Yi Z, Cho SG, Luo J, Pandey MK, Aggarwal BB, et al.: Gambogic Acid Inhibits Angiogenesis and Prostate Tumor Growth by Suppressing Vascular Endothelial Growth Factor Receptor 2 Signaling. Cancer Research 2008, 68(6):1843-1850.

[42] Liu W, Guo Q-L, You Q-D, Zhao L, Gu H-Y, Yuan S-T: Anticancer Effect and Apoptosis Induction of Gambogic 
Acid in Human Gastric Cancer Line BGC-823. World Journal of Gastroenterology 2005, 11(24):3655-3659.

[43] Reutrakul V, Anantachoke N, Pohmakotr M, Jaipetch T, Sophasan S, Yoosook C, et al.: Cytotoxic and Anti-HIV-1 Caged Xanthones from the Resin and Fruits of Garcinia hanburyi. Planta Medica 2007, 73(1):33-40.

[44] Liu Y, Li W, Ye C, Lin Y, Cheang T-Y, Wang M, et al.: Gambogic Acid Induces G0/G1 Cell Cycle Arrest and Cell Migration Inhibition Via Suppressing PDGF Receptor $\beta$ Ttyrosine Phosphorylation and Rac1 Activity in Rat Aortic Smooth Muscle Cells. Journal of Atherosclerosis and Thrombosis 2010, 17(9):901-913.

[45] Jang S-W, Okada M, Sayeed I, Xiao G, Stein D, Jin P, et al.: Gambogic Amide, a Selective Agonist for TrkA Receptor that Possesses Robust Neurotrophic Activity, Prevents Neuronal Cell Death. Proceedings of the National Academy of Sciences 2007, 104(41):16329-16334.

[46] Chantarasriwong O, Batova A, Chavasiri W, Theodorakis EA: Chemistry and Biology of the Caged Garcinia Xanthones. Chemistry 2010, 16(33):9944-9962.

[47] Anantachoke N, Tuchinda P, Kuhakarn C, Pohmakotr M, Reutrakul V: Prenylated Caged Xanthones: Chemistry and Biology. Pharmaceutical Biology 2012, 50(1):78-91.

[48] Vieira LMM, Kijjoa A: Naturally-occurring Xanthones: Recent Developments. Current Medicinal Chemistry 2005, 12(21):2413-2446.

[49] El-Seedi HR, El-Ghorab DMH, El-Barbary MA, Zayed MF, Goransson U, Larsson S, et al.: Naturally Occurring Xanthones; Latest Investigations: Isolation, Structure Elucidation and Chemosystematic Significance. Current Medicinal Chemistry 2009, 16(20):2581-2626.

[50] El-Seedi HR, El-Barbary MA, El-Ghorab DMH, Bohlin L, BorgKarlson A-K, Goransson U, et al.: Recent Insights Into the Biosynthesis and Biological Activities of Natural Xanthones. Current Medicinal Chemistry 2010, 17(9):854-901.

[51] Hemshekhar M, Sunitha K, Santhosh MS, Devaraja S, Kemparaju K, Vishwanath BS, et al.: An Overview on Genus Garcinia: Phytochemical and Therapeutical Aspects. Phytochemistry Reviews 2011, 10(3):325-351.

[52] Borzdziłowska P, Bednarek I: Xanthones as Natural Compounds with a wide Spectrum of Biological Activity. Postepy Higieny I Medycyny Doswiadczalnej 2018, 72:767-780.

[53] Araujo J, Fernandes C, Pinto M, Tiritan ME: Chiral Derivatives of Xanthones with Antimicrobial Activity. Molecules 2019, 24(2):314.

[54] Fernandes C, Carraro ML, Ribeiro J, Araujo J, Tiritan ME, Pinto MMM: Synthetic Chiral Derivatives of Xanthones: Biological Activities and Enantioselectivity Studies. Molecules 2019, 24(4):791.

[55] Ribeiro J, Veloso C, Fernandes C, Tiritan ME, Pinto MMM: Carboxyxanthones: Bioactive Agents and Molecular Scaffold for Synthesis of Analogues and Derivatives. Molecules 2019, 24(1):180.

[56] Gunter NV, the SS, Lim YM, Mah SH: Natural Xanthones and Skin Inflammatory Diseases: Multitargeting Mechanisms of Action and Potential Application. Frontiers in Pharmacology 2020, 11:594202.

[57] Wang X, Chen W: Gambogic Acid is a Novel Anti-cancer Agent that Inhibits Cell Proliferation, Angiogenesis and Metastasis. Anti-Cancer Agents in Medicinal Chemistry 2012, 12(8):994-1000.

[58] Kashyap D, Mondal R, Tuli HS, Kumar G, Sharma AK: Molecular Targets of Gambogic Acid in Cancer: Recent
Trends and Advancements. Tumour Biology 2016, 37(10):12915-12925.

[59] Hatami E, Jaggi M, Chauhan SC, Yallapu MM: Gambogic Acid: A Shining Natural Compound to Nanomedicine for Cancer Therapeutics. Biochimica et Biophysica Acta Reviews on Cancer 2020, 1874(1):188381.

[60] Jia B, Li S, Hu X, Zhu G, Chen W: Recent Research on Bioactive Xanthones from Natural Medicine: Garcinia hanburyi. AAPS PharmSciTech 2015, 16(4):742-758.

[61] Brahmachari G: Gambogic Acid: A Caged Prenylated Garcinia Xanthone Potent Anticancer Agent of Pharmaceutical Promise. In Chemistry and Pharmacology of Naturally Occurring Bioactive Compounds. Edited by Brahmachari G. 2013:393-415.

[62] Asano J, Chiba K, Tada M, Yoshii T: Cytotoxic Xanthones from Garcinia hanburyi. Phytochemistry 1996, 41(3):815-820.

[63] Thoison O, Cuong DD, Gramain A, Chiaroni A, Hung NV, Sévenet T: Further Rearranged Prenylxanthones and Benzophenones from Garcinia bracteata. Tetrahedron 2005, 61(35):8529-8535.

[64] Chen $Y$, Xue Q, Teng $H$, Qin R, Liu $H$, Xu J, et al.: Acylphloroglucinol Derivatives with a Tricyclo-[4.4.1.1 1,4] Dodecane Skeleton from Garcinia bracteata Fruits. The Journal of Organic Chemistry 2020, 85(10):6620-6625.

[65] Pepper HP, Lam HC, Bloch WM, George JH: Biomimetic Total Synthesis of $( \pm)$-garcibracteatone. Organic Letters 2012, 14(19):5162-5164.

[66] Pepper HP, Tulip SJ, Nakano Y, George JH: Biomimetic Total Synthesis of $( \pm)$-doitunggarcinone $A$ and (+)-garcibracteatone. The Journal of Organic Chemistry 2014, 79(6):2564-2573.

[67] Shen T, Li W, Wang Y-Y, Zhong Q-Q, Wang S-Q, Wang X-N, et al.: Antiproliferative Activities of Garcinia bracteata Extract and its Active Ingredient, Isobractatin, Against Human Tumor Cell Lines. Archives of Pharmacal Research 2014, 37(3):412-420.

[68] Gao XM, Yu T, Cui MZ, Pu JX, Du X, Han QB, Hu QF, et al.: Identification and Evaluation of Apoptotic Compounds from Garcinia oligantha. Bioorganic and Medicinal Chemistry Letters 2012, 22(6):2350-2353.

[69] Xu D, Lao Y, Xu N, Hu H, Fu W, Tan H, et al.: Identification and Characterization of Anticancer Compounds Targeting Apoptosis and Autophagy from Chinese Native Garcinia Species. Planta Medica 2015, 81(1):79-89.

[70] Xu L, Lao Y, Zhao Y, Qin J, Fu W, Zhang Y, et al.: Screening Active Compounds from Garcinia Species Native to China Reveals Novel Compounds Targeting the STAT/JAK Signaling Pathway. BioMed Research International 2015, 2015:910453.

[71] Gu H, Rao S, Zhao J, Wang J, Mu R, Rong J, et al.: Gambogic Acid Reduced Bcl-2 Expression Via p53 in Human Breast MCF-7 Cancer Cells. Journal of Cancer Research and Clinical Oncology 2009, 135(12):1777-1782.

[72] Zhu M, Jiang Y, Wu H, Shi W, Lu G, Cong D, et al.: Gambogic Acid Shows Anti-proliferative Effects on Non-small Cell Lung Cancer (NSCLC) Cells by Activating Reactive Oxygen Species (ROS)-induced Endoplasmic Reticulum (ER) Stressmediated Apoptosis. Medical Science Monitor 2019, 25:3983.

[73] Nie F, Zhang X, Qi Q, Yang L, Yang Y, Liu W, et al.: Reactive Oxygen Species Accumulation Contributes to Gambogic Acid-induced Apoptosis in Human Hepatoma SMMC-7721 Cells. Toxicology 2009, 260(1):60-67. 
[74] Huang G-M, Sun Y, Ge X, Wan X, Li C-B: Gambogic Acid Induces Apoptosis and Inhibits Colorectal Tumor Growth Via Mitochondrial Pathways. World Journal of Gastroenterology 2015, 21(20):6194.

[75] Lü L, Tang D, Wang L, Huang L-Q, Jiang G-S, Xiao X-Y, et al.: Gambogic Acid Inhibits TNF- $\alpha$-induced Invasion of Human Prostate Cancer PC3 Cells In Vitro Through PI3K/ Akt and NF-KB Signaling Pathways. Acta Pharmacologica Sinica 2012, 33(4):531-541.

[76] Li C-Y, Wang Q, Wang X-M, Li G-X, Shen S, Wei X-L: Gambogic Acid Exhibits Anti-metastatic Activity on Malignant Melanoma Mainly Through Inhibition of PI3K/ Akt and ERK Signaling Pathways. European Journal of Pharmacology 2019, 864:172719.

[77] Chen J, Gu H-Y, Lu N, Yang Y, Liu W, Qi Q, et al.: Microtubule Depolymerization and Phosphorylation of c-Jun N-terminal Kinase-1 and p38 were Involved in Gambogic Acid Induced Cell Cycle Arrest and Apoptosis in Human Breast Carcinoma MCF-7 Cells. Life Sciences 2008 83(3):103-109.

[78] Liang L, Zhang Z: Gambogic Acid Inhibits Malignant Melanoma Cell Proliferation Through Mitochondrial p66shc/ROS-p53/Bax-mediated Apoptosis. Cellular Physiology and Biochemistry 2016, 38(4):1618-1630.

[79] Krajarng A, Imoto M, Tashiro E, Fujimaki T, Shinjo S, Watanapokasin R: Apoptosis Induction Associated with the ER Stress Response Through Up-regulation of JNK in HeLa Cells by Gambogic Acid. BMC Complementary and Alternative Medicine 2015, 15(1):1-9.

[80] Zhao T, Wang H-J, Zhao W-W, Sun Y-L, Hu L-K: Gambogic Acid Improves Non-small Cell Lung Cancer Progression by Inhibition of mTOR Signaling Pathway. The Kaohsiung Journal of Medical Sciences 2017, 33(11):543-549.

[81] Luo G-X, Cai J, Lin J-Z, Luo W-S, Luo H-S, Jiang Y-Y, et al.: Autophagy Inhibition Promotes Gambogic Acid-induced Suppression of Growth and Apoptosis in Glioblastoma Cells. Asian Pacific Journal of Cancer Prevention 2012, 13(12):6211-6216.

[82] Pandey MK, Sung $B$, Ahn KS, Kunnumakkara $A B$, Chaturvedi MM, Aggarwal BB: Gambogic Acid, a Novel Ligand for Transferrin Receptor, Potentiates TNF-induced Apoptosis Through Modulation of the Nuclear Factor- $\mathrm{\kappa B}$ Signaling Pathway. Blood 2007, 110(10):3517-3525.

[83] Park M-S, Kim N-H, Kang C-W, Oh C-W, Kim G-D: Antimetastatic Effects of Gambogic Acid are Mediated Via the Actin Cytoskeleton and NF-KB Pathways in SK-HEP1 Cells. Drug Development Research 2015, 76(3):132-142.

[84] Yang $Y$, Sun $X$, Yang $Y$, Yang $X$, Zhu H, Dai S, et al.: Gambogic Acid Enhances the Radiosensitivity of Human Esophageal Cancer Cells by Inducing Reactive Oxygen Species Via Targeting Akt/mTOR Pathway. Tumor Biology 2016, 37(2):1853-1862.

[85] Wang J, Yuan Z: Gambogic Acid Sensitizes Ovarian Cancer Cells to Doxorubicin Through ROS-mediated Apoptosis. Cell Biochemistry and Biophysics 2013, 67(1):199-206.

[86] Wang LH, Li Y, Yang SN, Wang FY, Hou Y, Cui W, et al.: Gambogic Acid Synergistically Potentiates Cisplatininduced Apoptosis in Non-small-cell Lung Cancer Through Suppressing NF-KB and MAPK/HO-1 Signalling. British Journal of Cancer 2014, 110(2):341-352.

[87] Pan H, Lu L, Wang X, Li B, Kelly K, Lin H: Gambogic Acid Induces Cell Apoptosis and Inhibits MAPK Pathway in $\mathrm{PTEN}^{-1-} / \mathrm{p} 3^{-/-}$Prostate Cancer Cells In Vitro and Ex Vivo. Chinese Journal of Integrative Medicine 2018, 24(2):109-116.
[88] Zou Z, Xie L, Wei J, Yu L, Qian X, Chen J, et al.: Synergistic Anti-proliferative Effects of Gambogic Acid with Docetaxel in Gastrointestinal Cancer Cell Lines. BMC Complementary and Alternative Medicine 2012, 12(1):58.

[89] Wang T, Wei J, Qian X, Ding Y, Yu L, Liu B: Gambogic Acid, a Potent Inhibitor of Survivin, Reverses Docetaxel Resistance in Gastric Cancer Cells. Cancer Letters 2008, 262(2):214-222

[90] Wang S, Wang L, Chen M, Wang Y: Gambogic Acid Sensitizes Resistant Breast Cancer Cells to Doxorubicin Through Inhibiting P-glycoprotein and Suppressing Survivin Expression. Chemico-Biological Interactions 2015, 235:76-84

[91] Wang H, Zhao Z, Lei S, Li S, Xiang Z, Wang X, Huang X, et al.: Gambogic Acid Induces Autophagy and Combines Synergistically with Chloroquine to Suppress Pancreatic Cancer by Increasing the Accumulation of Reactive Oxygen Species. Cancer Cell International 2019, 19:7.

[92] Bishayee K, Habib K, Sadra A, Huh S-O: Targeting the Difficult-to-drug CD71 and MYCN with Gambogic Acid and Vorinostat in a Class of Neuroblastomas. Cellular Physiology and Biochemistry 2019, 53:258-280.

[93] Wei J, Yang P, Li W, He F, Zeng S, Zhang T, et al.: Gambogic Acid Potentiates the Chemosensitivity of Colorectal Cancer Cells to 5-fluorouracil by Inhibiting Proliferation and Inducing Apoptosis. Experimental and Therapeutic Medicine 2017, 13(2):662-668.

[94] Liu L, Qi X-J, Zhong Z-K, Zhang E-N: Nanomedicinebased Combination of Gambogic Acid and Retinoic Acid Chlorochalcone for Enhanced Anticancer Efficacy in Osteosarcoma. Biomedicine and Pharmacotherapy 2016, 83:79-84.

[95] Ning R, Wang X-P, Zhan Y-R, Qi Q, Huang X-F, Hu G, et al.: Gambogic Acid Potentiates Clopidogrel-induced Apoptosis and Attenuates Irinotecan-induced Apoptosis Through Down-regulating Human Carboxylesterase 1 and -2. Xenobiotica 2016, 46(9):816-824.

[96] Yang Y, Yang L, You Q-D, Nie F-F, Gu H-Y, Zhao L, et al.: Differential Apoptotic Induction of Gambogic Acid, a Novel Anticancer Natural Product, on Hepatoma Cells and Normal Hepatocytes. Cancer Letters 2007, 256(2):259-266.

[97] Batova A, Lam T, Wascholowski V, Yu AL, Giannis A, Theodorakis EA: Synthesis and Evaluation of Caged Garcinia Xanthones. Organic \& Biomolecular Chemistry 2007, 5(3):494-500.

[98] Batova A, Altomare D, Chantarasriwong O, Ohlsen KL, Creek KE, Lin YC, et al.: The Synthetic Caged Garcinia Xanthone Cluvenone Induces Cell Stress and Apoptosis and has Immune Modulatory Activity. Molecular Cancer Therapeutics 2010, 9(11):2869-2878.

[99] Chantarasriwong O, Cho WC, Batova A, Chavasiri W, Moore C, Rheingold AL, et al.: Evaluation of the Pharmacophoric Motif of the Caged Garcinia Xanthones. Organic \& Biomolecular Chemistry 2009, 7(23):4886-4894.

[100] Guizzunti G, Theodorakis EA, Yu AL, Zurzolo C, Batova A: Cluvenone Induces Apoptosis Via a Direct Target in Mitochondria: A Possible Mechanism to Circumvent Chemo-resistance? Investigational New Drugs 2012, 30(5):1841-1848.

[101] Elbel KM, Guizzunti G, Theodoraki MA, Xu J, Batova A, Dakanali M, et al.: A-ring Oxygenation Modulates the Chemistry and Bioactivity of Caged Garcinia 
Xanthones. Organic \& Biomolecular Chemistry 2013, 11(20):3341-3348.

[102] Wang X, Lu N, Yang Q, Gong D, Lin C, Zhang S, et al.: Studies on Chemical Modification and Biology of a Natural Product, Gambogic Acid (III): Determination of the Essential Pharmacophore for Biological Activity. European Journal of Medicinal Chemistry 2011, 46(4):1280-1290.

[103] Chantarasriwong O, Dorwart TJ, Morales TH, Maggio SF, Settle AL, Milcarek AT, et al.: Chiral Resolution of a Caged Xanthone and Evaluation Across a Broad Spectrum of Breast Cancer Subtypes. Bioorganic Chemistry 2019, 93:103303.

[104] Zhang X, Li X, Sun H, Wang X, Zhao L, Gao Y, et al.: Garcinia Xanthones as Orally Active Antitumor Agents. Journal of Medicinal Chemistry 2013, 56(1):276-292.

[105] Zhang X, Li X, Sun H, Jiang Z, Tao L, Gao Y, et al.: Synthesis and Evaluation of Novel Aza-caged Garcinia Xanthones. Organic \& Biomolecular Chemistry 2012, 10(16):3288-3299.

[106] Xu X, Wu Y, Hu M, Li X, Bao Q, Bian J, et al.: Novel Natural Product-like Caged Xanthones Bearing a Carbamate Moiety Exhibit Antitumor Potency and Antiangiogenesis Activity In vivo. Scientific Reports 2016, 6:35771.

[107] Li X, Wu Y, Wang Y, You Q, Zhang X: 'Click Chemistry' Synthesis of Novel Natural Product-like Caged Xanthones Bearing a 1,2,3-triazole Moiety with Improved Druglike Properties as Orally Active Antitumor Agents. Molecules 2017, 22(11):1834.

[108] Wu Y, Hu M, Yang L, Li X, Bian J, Jiang F, et al.: Novel Natural-product-like Caged Xanthones with Improved Druglike Properties and In vivo Antitumor Potency. Bioorganic and Medicinal Chemistry Letters 2015, 25(12):2584-2588

[109] Xu X, Wu Y, Hu M, Li X, Gu C, You Q, et al.: Structureactivity Relationship of Garcinia Xanthones Analogues: Potent Hsp90 Inhibitors with Cytotoxicity and Antiangiogenesis Activity. Bioorganic \& Medicinal Chemistry 2016, 24(19):4626-4635.

[110] Li Q, Cheng H, Zhu G, Yang L, Zhou A, Wang X, et al.: Gambogenic Acid Inhibits Proliferation of A549 Cells Through Apoptosis-inducing and Cell Cycle Arresting. Biological and Pharmaceutical Bulletin 2010, 33(3):415-420.

[111] Huang T, Zhang $H$, Wang $X, X u L$, Jia J, Zhu X: Gambogenic Acid Inhibits the Proliferation of Small-cell Lung Cancer Cells by Arresting the Cell Cycle and Inducing Apoptosis. Oncology Reports 2019, 41(3):1700-1706.

[112] Shen D, Wang Y, Niu H, Liu C: Gambogenic Acid Exerts Anticancer Effects in Cisplatin-resistant Non-small Cell Lung Cancer Cells. Molecular Medicine Reports 2020, 21(3):1267-1275.

[113] Yan F, Wang $M$, Chen $H$, Su J, Wang $X$, Wang F, et al.: Gambogenic Acid Mediated Apoptosis Through the Mitochondrial Oxidative Stress and Inactivation of Akt Signaling Pathway in Human Nasopharyngeal Carcinoma CNE-1 Cells. European Journal of Pharmacology 2011, 652(1):23-32.

[114] Zhou L-Z: Study on the Mechanism of Gambogenic Acidinduced Apoptosis of Human Colon Cancer HCT116 Cells. Tumor 2011, 12:580-584.

[115] Chen H-B, Zhou L-Z, Mei L, Shi X-J, Wang X-S, Li Q-L, et al.: Gambogenic Acid-induced Time-and Dose-dependent
Growth Inhibition and Apoptosis Involving Akt Pathway Inactivation in U251 Glioblastoma Cells. Journal of Natural Medicines 2012, 66(1):62-69.

[116] Zhou J, Luo Y-H, Wang J-R, Lu B-B, Wang K-M, Tian Y: Gambogenic Acid Induction of Apoptosis in a Breast Cancer Cell Line. Asian Pacific Journal of Cancer Prevention 2013, 14(12):7601-7605.

[117] Wang X, Zhu G, Cheng H, Li Q: Gambogenic Acid Induces Mitochondria-dependent Apoptosis in Human Gastric Carcinoma Cell Line. Journal of Chinese Medicinal Materials 2014, 37(1):95-99.

[118] Li F, Wang Y, Yan Y: Gambogenic Acid Induces Cell Growth Inhibition, Cell Cycle Arrest and Metastasis Inhibition in Choroidal Melanoma in a Dose-dependent Manner. Experimental and Therapeutic Medicine 2017, 13(5):2456-2462.

[119] Cheng $H$, Su J-J, Peng J-Y, Wang M, Wang X-C, Yan F-G, et al.: Gambogenic Acid Inhibits Proliferation of A549 Cells Through Apoptosis Inducing Through Up-regulation of the p38 MAPK Cascade. Journal of Asian Natural Products Research 2011, 13(11):993-1002.

[120] Yan F, Wang M, Li J, Cheng H, Su J, Wang X, Wu H, et al.: Gambogenic Acid Induced Mitochondrial-dependent Apoptosis and Referred to Phospho-Erk1/2 and Phospho-p38 MAPK in Human Hepatoma HepG2 Cells. Environmental Toxicology and Pharmacology 2012, 33(2):181-190.

[121] Cheng H, Zhang X, Su J-J, Li Q-L: Study of Gambogenic Acid-induced Apoptosis of Melanoma B16 Cells Through PI3K/Akt/mTOR Signaling Pathways. China Journal of Chinese Materia Medica 2014, 39(9):1666-1669.

[122] Lu Y, Li Q: Study on the Mechanism of Mitochondrial Autophagy in Melanoma B16 Cell Induced by Gambogenic Acid. Modern Journal of Integrated Traditional Chinese and Western Medicine 2016, 2016:19.

[123] Wang M, Li S, Wang Y, Cheng H, Su J, Li Q: Gambogenic Acid Induces Ferroptosis in Melanoma Cells Undergoing Epithelial-to-mesenchymal Transition. Toxicology and Applied Pharmacology 2020, 401:115110.

[124] YuXJ, Zhao Q, Wang XB, Zhang JX, Wang XB: Gambogenic Acid Induces Proteasomal Degradation of CIP2A and Sensitizes Hepatocellular Carcinoma to Anticancer Agents. Oncology Reports 2016, 36(6):3611-3618.

[125] Ding $Z$, Li $Y$, Tang $Z$, Song $X$, Jing $F, W u ~ H$, et al.: Role of Gambogenic Acid in Regulating PI3K/Akt/NF-k $\beta$ Signaling Pathways in Rat Model of Acute Hepatotoxicity. Bioscience, Biotechnology, and Biochemistry 2021, 85(3):520-527

[126] Zhou S, Zhao N, Wang J: Gambogenic Acid Suppresses Bladder Cancer Cells Growth and Metastasis by Regulating NF- $\mathrm{KB}$ Signaling. Chemical Biology \& Drug Design 2020, 96(5):1272-1279.

[127] Xu Q, Guo J, Chen W: Gambogenic Acid Reverses P-glycoprotein Mediated Multidrug Resistance in HepG2/Adr Cells and its Underlying Mechanism. Biochemical and Biophysical Research Communications 2019, 508(3):882-888.

[128] Yu X-J, Han Q-B, Wen Z-S, Ma L, Gao J, Zhou G-B: Gambogenic Acid Induces G1 Arrest Via GSK3ß-dependent Cyclin D1 Degradation and Triggers Autophagy in Lung Cancer Cells. Cancer Letters 2012, 322(2):185-194.

[129] Mei W, Dong C, Hui C, Bin L, Fenggen $Y$, Jingjing $S$, et al.: Gambogenic Acid Kills Lung Cancer Cells Through Aberrant Autophagy. PloS One 2014, 9(1):e83604. 
[130] Xu L, Meng X, Xu N, Fu W, Tan H, Zhang L, et al.: Gambogenic Acid Inhibits Fibroblast Growth Factor Receptor Signaling Pathway in Erlotinib-resistant Nonsmall-cell Lung Cancer and Suppresses Patient-derived Xenograft Growth. Cell Death \& Disease 2018, 9(3):1-14.

[131] Su J, Cheng H, Zhang D, Wang M, Xie C, Hu Y, et al.: Synergistic Effects of 5-Fluorouracil and Gambogenic Acid on A549 Cells: Activation of Cell Death Caused by Apoptotic and Necroptotic Mechanisms via the ROSMitochondria Pathway. Biological and Pharmaceutical Bulletin 2014, 37(8):1259-1268.

[132] Su J, Xu T, Jiang G, Hou $M$, Liang $M$, Cheng $H$, et al.: Gambogenic Acid Triggers Apoptosis in Human Nasopharyngeal Carcinoma CNE-2Z Cells by activating Volume-Sensitive Outwardly Rectifying Chloride Channel. Fitoterapia 2019, 133:150-158.

[133] Zhao Q, Zhong J, Bi Y, Liu Y, Liu Y, Guo J, et al.: Gambogenic Acid Induces Noxa-Mediated Apoptosis in Colorectal Cancer Through ROS-Dependent Activation of IRE1 $\alpha / J N K$. Phytomedicine 2020, 78:153306.

[134] Liu C, Xu J, Guo C, Chen X, Qian C, Zhang X, et al.: Gambogenic Acid Induces Endoplasmic Reticulum Stress in Colorectal Cancer via the Aurora A Pathway. Frontiers in Cell and Developmental Biology 2021, 9:736350.

[135] Liu P, Wu X, Dai L, Ge Z, Gao C, Zhang H, et al.: Gambogenic Acid Exerts Antitumor Activity in Hypoxic Multiple Myeloma Cells by Regulation of miR-21. Journal of Cancer 2017, 8(16):3278.

[136] Chen R, Zhang H, Liu P, Wu X, Chen B: Gambogenic Acid Synergistically Potentiates Bortezomib-Induced Apoptosis in Multiple Myeloma. Journal of Cancer 2017, 8(5):839.

[137] He Y, Ding J, Lin Y, Li J, Shi Y, Wang J, et al.: Gambogenic Acid Alters Chemosensitivity of Breast Cancer Cells to Adriamycin. BMC Complementary and Alternative Medicine 2015, 15(1):1-8.

[138] Pesonen L, Svartsjo S, Back V, de Thonel A, Mezger V, Saberan-Djoneidi D, et al.: Gambogic Acid and Gambogenic Acid Induce a Thiol-Dependent Heat Shock Response and Disrupt the Interaction Between HSP90 and HSF1 or HSF2. Cell Stress Chaperones 2021, 26(5):819-833.

[139] Jolly C, Morimoto RI: Role of the Heat Shock Response and Molecular Chaperones in Oncogenesis and Cell Death. JNCl: Journal of the National Cancer Institute 2000, 92(19):1564-1572.

[140] Hahnvajanawong C, Boonyanugomol W, Nasomyon T, Loilome W, Namwat N, Anantachoke N, et al.: Apoptotic Activity of Caged Xanthones from Garcinia hanburyi in Cholangiocarcinoma Cell Lines. World Journal of Gastroenterology 2010, 16(18):2235-2243.

[141] Hahnvajanawong C, Ketnimit S, Pattanapanyasat K, Anantachoke N, Sripa B, Pinmai K, et al.: Involvement of p53 and Nuclear Factor-kappaB Signaling Pathway for the Induction of G1-Phase Cell Cycle Arrest of Cholangiocarcinoma Cell Lines by Isomorellin. Biological \& Pharmaceutical Bulletin 2012, 35(11):1914-1925.

[142] Hahnvajanawong C, Sahakulboonyarak T, Boonmars T, Reutrakul V, Kerdsin A, Boueroy P: Inhibitory Effect of Isomorellin on Cholangiocarcinoma Cells via Suppression of NF- $\kappa B$ Translocation, the Phosphorylated p38 MAPK Pathway and MMP-2 and UPA Expression. Experimental and Therapeutic Medicine 2021, 21(2):151.

[143] Hahnvajanawong C, Wattanawongdon W, Chomvarin C, Anantachoke N, Kanthawong S, Sripa B, et al.:
Synergistic Effects of Isomorellin and Forbesione with Doxorubicin on Apoptosis Induction in Human Cholangiocarcinoma Cell Lines. Cancer Cell International 2014, 14(1):1-15.

[144] Boueroy P, Hahnvajanawong C, Boonmars T, SaensaArd S, Anantachoke N, Vaeteewoottacharn K, et al.: Antitumor Effect of Forbesione Isolated from Garcinia hanburyi on Cholangiocarcinoma In Vitro and In vivo. Oncology Letters 2016, 12(6):4685-4698.

[145] Zheng Z, Wu M, Zhang J, Fu W, Xu N, Lao Y, et al.: The Natural Compound Neobractatin Induces Cell Cycle Arrest by Regulating E2F1 and Gadd $45 \alpha$. Frontiers in Oncology 2019, 9:654.

[146] Zhang J, Zheng Z, Wu M, Zhang L, Wang J, Fu W, et al.: The Natural Compound Neobractatin Inhibits Tumor Metastasis by Upregulating the RNA-Binding-Protein MBNL2. Cell Death \& Disease 2019, 10(8):1-13.

[147] Huang H, Peng Y, Zhou T, Zhou X, Deng J, Yang X, et al.: A Composition of Bractatin and Neobractatin from the Fruits of Garcinia bracteata Induces Apoptosis in Throat Cancer Through the Endoplasmic Reticulum Stress, Mitochondrial Apoptotic and Akt Pathways. Journal of Functional Foods 2021, 84:104585.

[148] Yu X, Zhao Q, Zhang H, Fan C, Zhang X, Xie Q, et al.: Gambogenic Acid Inhibits LPS-Simulated Inflammatory Response by Suppressing NF- $\kappa B$ and MAPK in Macrophages. Acta Biochimica et Biophysica Sinica 2016, 48(5):454-461

[149] Jiang Y, Xiao L, Fu W, Tang Y, Lertnimitphun P, Kim N, et al.: Gaudichaudione $\mathrm{H}$ Inhibits Inflammatory Responses in Macrophages and Dextran Sodium Sulfate-Induced Colitis in Mice. Frontiers in Pharmacology 2020, 10:1561.

[150] Huang T-Y, Wang Z-Z, Gong Y-F, Liu X-C, Zhang X-M, Huang $X-Y$ : Scar-Reducing Effects of Gambogenic Acid on Skin Wounds in Rabbit Ears. International Immunopharmacology 2021, 90:107200.

[151] Tan XF, Uddin Z, Park C, Song YH, Son M, Lee KW, et al.: Competitive Protein Tyrosine Phosphatase 1B (PTP1B) Inhibitors, Prenylated Caged Xanthones from Garcinia hanburyi and Their Inhibitory Mechanism. Bioorganic \& Medicinal Chemistry 2017, 25(8):2498-2506.

[152] Través PG, Pardo V, Pimentel-Santillana M, GonzálezRodríguez Á, Mojena M, Rico D, et al.: Pivotal Role of Protein Tyrosine Phosphatase 1B (PTP1B) in the Macrophage Response to Pro-Inflammatory and Anti-Inflammatory Challenge. Cell Death \& Disease 2014, 5(3):e1125.

[153] Ukkola O, Santaniemi M: Protein Tyrosine Phosphatase 1B: a New Target for the Treatment of Obesity and Associated Co-Morbidities. Journal of Internal Medicine 2002, 251(6):467-475.

[154] Hilmarsdottir B, Briem E, Halldorsson S, Kricker J, Ingthorsson S, Gustafsdottir S, et al.: Inhibition of PTP1B Disrupts Cell-Cell Adhesion and Induces Anoikis in Breast Epithelial Cells. Cell Death \& Disease 2017, 8(5):e2769.

[155] Jin YM, Kim JY, Lee SM, Tan XF, Park KH: $\alpha$-Glucosidase Inhibitory Caged Xanthones From the Resin of Garcinia hanburyi. Journal of Applied Biological Chemistry 2019, 62(1):81-86.

[156] Chaiyakunvat $P$, Anantachoke N, Reutrakul V, Jiarpinitnun C: Caged Xanthones: Potent Inhibitors of Global Predominant MRSA USA300. Bioorganic and Medicinal Chemistry Letters 2016, 26(13):2980-2983.

[157] Ke H, Morrisey JM, Qu S, Chantarasriwong O, Mather MW, Theodorakis EA, et al.: Caged Garcinia Xanthones, 
a Novel Chemical Scaffold with Potent Antimalarial Activity. Antimicrobial Agents and Chemotherapy 2017, 61(1):e01220.

[158] Sun H, Chen F, Wang X, Liu Z, Yang Q, Zhang X, et al.: Studies on Gambogic Acid (IV): Exploring StructureActivity Relationship with IкB Kinase- $\beta$ (IKK $\beta$ ). Eur J Med Chem 2012, 51:110-123.

[159] Zhang HZ, Kasibhatla S, Wang Y, Herich J, Guastella J, Tseng B, et al.: Discovery, Characterization and SAR of Gambogic Acid as a Potent Apoptosis Inducer by a HTS Assay. Bioorganic \& Medicinal Chemistry 2004, 12(2):309-317.

[160] Kuemmerle J, Jiang S, Tseng B, Kasibhatla S, Drewe J, Cai SX: Synthesis of Caged 2,3,3a,7a-tetrahydro-3,6methanobenzofuran-7(6H)-ones: Evaluating the Minimum Structure for Apoptosis Induction by Gambogic Acid. Bioorganic \& Medicinal Chemistry 2008, 16(8):4233-4241.

[161] Li X, Zhang X, Wang X, Li N, Lin C, Gao Y, et al.: Synthesis and Anti-Tumor Evaluation of B-Ring Modified Caged Xanthone Analogues of Gambogic Acid. Chinese Journal of Chemistry 2012, 30(1):35-42.

[162] Miao G, Ma J, Yang K, Huang Z, Gu Q, Wang Y, et al.: Synthesis and Bioevaluation of Novel Oxa-Caged Garcinia Xanthones as Anti-Tumour Agents. Australian Journal of Chemistry 2015, 68(6):872-880.

[163] Chantarasriwong O, Milcarek AT, Morales TH, Settle AL, Rezende CO, Jr., Althufairi BD, et al.: Synthesis, StructureActivity Relationship and In Vitro Pharmacodynamics of
A-Ring Modified Caged Xanthones in a Preclinical Model of Inflammatory Breast Cancer. European Journal of Medicinal Chemistry 2019, 168:405-413.

[164] Wang J, Zhao L, Hu Y, Guo Q, Zhang L, Wang X, et al.: Studies on Chemical Structure Modification and Biology of a Natural Product, Gambogic Acid (I): Synthesis and Biological Evaluation of Oxidized Analogues of Gambogic Acid. European Journal of Medicinal Chemistry 2009, 44(6):2611-2620.

[165] Guo X-K, Sun H-P, Shen S, Sun Y, Xie F-L, Tao L, et al.: Synthesis and Evaluation of Gambogic Acid Derivatives as Antitumor Agents. Part III. Chemistry \& Biodiversity 2013, 10(1):73-85.

[166] Sun H-P, Liu Z-L, Xue X, Gao Y, Zhang L, Wang J-X, et al.: Studies on Chemical Structure Modification and Structure Activity Relationship of Derivatives of Gambogic Acid at C(39). Chemistry \& Biodiversity 2012, 9(8):1579-1590.

[167] Zhang X-J, Li X, Yang Y-R, Sun H-P, Gao Y, Zhang L, et al.: Studies on Chemical-Structure Modification and Structure Activity Relationship of Gambogic acid Derivatives at Carbon(34). Chemistry \& Biodiversity 2012, 9(10):2295-2308.

[168] Li X, Zhang X, Sun H, Zhang L, Gao Y, Wang J, et al.: Synthesis and Anti-Tumor Evaluation of Novel C-37 Modified Derivatives of Gambogic Acid. Chinese Journal of Chemistry 2012, 30(5):1083-1091. 